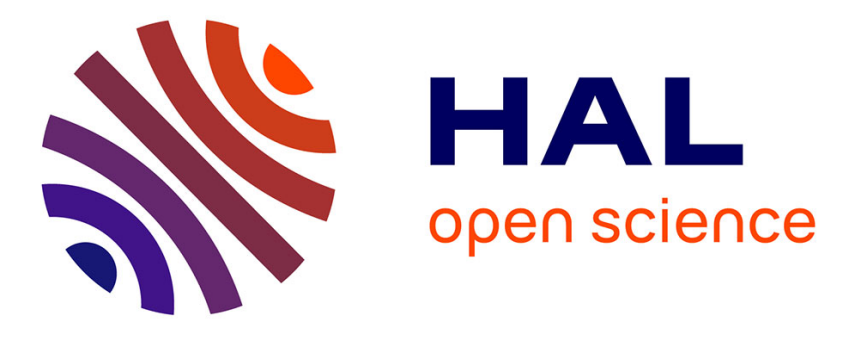

\title{
Co-doped LaAlO3 perovskite oxide for NOx-assisted soot oxidation
}

\author{
Quang Nguyen Tran, Ferenc Martinovic, Monica Ceretti, Serena Esposito, \\ Barbara Bonelli, Werner Paulus, Francesco Di Renzo, Fabio Deorsola, Samir \\ Bensaid, Raffaele Pirone
}

\section{To cite this version:}

Quang Nguyen Tran, Ferenc Martinovic, Monica Ceretti, Serena Esposito, Barbara Bonelli, et al.. Co-doped LaAlO3 perovskite oxide for NOx-assisted soot oxidation. Applied Catalysis A: General, 2020, 589, pp.117304. 10.1016/j.apcata.2019.117304 . hal-02336296

\section{HAL Id: hal-02336296 https://hal.science/hal-02336296}

Submitted on 2 Dec 2020

HAL is a multi-disciplinary open access archive for the deposit and dissemination of scientific research documents, whether they are published or not. The documents may come from teaching and research institutions in France or abroad, or from public or private research centers.
L'archive ouverte pluridisciplinaire HAL, est destinée au dépôt et à la diffusion de documents scientifiques de niveau recherche, publiés ou non, émanant des établissements d'enseignement et de recherche français ou étrangers, des laboratoires publics ou privés. 


\title{
Co-doped LaAlO3 perovskite oxide for NOx-assisted soot oxidation
}

Quang Nguyen Tran ${ }^{\mathrm{a}, \mathrm{b}}$, Ferenc Martinovic ${ }^{\mathrm{a}}$, Monica Ceretti ${ }^{\mathrm{b}}$, Serena Esposito ${ }^{\mathrm{a}}$, Barbara Bonellia, Werner Paulus ${ }^{\mathrm{b}}$, Francesco Di Renzo ${ }^{\mathrm{b}}$, Fabio A. Deorsola ${ }^{\mathrm{a}},{ }^{*}$, Samir Bensaida, Raffaele Pirone $^{\mathrm{a}}$

a Department of Applied Science and Technology, Politecnico di Torino, Corso Duca degli Abruzzi, 24, 10129 Torino, Italy

$\mathrm{b}$ Institut Charles Gerhardt, Université de Montpellier-CNRS-ENSCM, Place Eugène Bataillon, 34095 Montpellier Cedex 5, France

Keywords: Soot; Oxidation; NOx-assistance; Perovskite; NOx storage; Oxygen mobility

Supplementary material: doi:https://doi.org/10.1016/j.apcata.2019.117304.

\begin{abstract}
In the framework of nowadays challenges in the automotive catalysis, directed to the mitigation of pollution caused by the emissions of internal combustion engines, a series of LaAl1-xCoxO3 perovskites were investigated with the purpose of enhancing the oxidation of soot in the presence of NOx. Perovskite oxides LaAl1-xCoxO3 ( $\mathrm{x}=0 ; 0.25 ; 0.5 ; 0.75$ and 1$)$ were synthesized by a solgel route and characterized by different methods: X-Ray diffraction (XRD), H2-temperature programmed reduction (H2-TPR), N2-sorption, O2/NOx-temperature programmed desorption (TPD) and X-ray photoelectron spectroscopy (XPS). The perovskite oxides were tested as catalysts for NO oxidation in isothermal mode and for NOx-assisted soot oxidation in temperature programmed reaction. Structural results reveal that $\mathrm{Co}$ is well incorporated in the perovskite structure expanding the unit cell, and doping Co may result in the distortion of the BO6 octahedra of the general $\mathrm{ABO} 3$ perovskite structure. An increase in Co substitution with $\mathrm{x}$ up to 0.75 remarkably promotes the oxidation activity, whereas total replacement of Al by Co degrades the catalytic performance. Among the prepared solids, LaA10.25Co0.75O3 is the most active for NO oxidation, with a conversion of $78 \%$ at $320{ }^{\circ} \mathrm{C}$, and it also exhibits the highest activity for NOxassisted soot oxidation, with a T10\% of $377^{\circ} \mathrm{C}$ while maintaining high NO2 production (71\%). The outstanding performance of LaA10.25Co0.75O3 is associated with the high mobility of lattice oxygen species and the role of surface adsorbed oxygen seems not to be prominent. The strong correlation of catalytic activity with NOx-TPD profiles suggests that NOx adsorption on catalyst surface is an essential step in soot oxidation. It is also shown that higher calcination temperature promotes the crystallinity of perovskite phase and leads to the improvement in the catalytic activity. The present work indicates that the prepared perovskite catalysts are competitive with noble-metal rivals for NOx-assisted soot oxidation and outperform them in NO2 production for further NOx abatement.
\end{abstract}

\section{Introduction}

Perovskite oxides have general formula $\mathrm{ABO} 3$, where the 12-fold cubo-octahedral A site is usually occupied by alkaline earth/alkaline or larger cations and the octahedral B-site by smaller cations [1]. The ideal structure of perovskite is cubic with tolerance factor $\mathrm{t}$ (so-called Goldschmidt factor) of $1\left(\mathrm{t}=\left(r_{A}+r_{O}\right) / \sqrt{2\left(\mathrm{r}_{B}+\mathrm{r}_{O}\right)}\right)$, where $r A, r B$ and $\mathrm{r} O$ are ionic radii of $\mathrm{A}, \mathrm{B}$, and oxygen, 
respectively) [2]. A t parameter between 0.75 and 1 is necessary to form perovskite structures, with decreasing symmetry for $\mathrm{t}<1$ [1]. Thanks to the wide range of metals able to adapt in the perovskite structures (about $90 \%$ of metallic elements in the periodic table), the physicochemical properties of perovskite oxides can be finely tuned and they find enormous applications in catalysis for, e. g., steam reforming of toluene [3-5], ethanol [6,7], $\mathrm{CH} 4$ [8-10] and bioglycerol [11]; valorization of bio-oil [12-15], biomass [16] and HMF [17], lignin partial oxidation [18,19] and environmental treatments [20-24].

Particulate matter (PM), which is normally referred as soot (although the latter strictly refers only to its carbonaceous fraction), is a noxious emission of diesel engines, which find enormous applications thanks to their high energy efficiency in fuel consumption [25]. PMs can cause a number of respiratory diseases [26] and deactivation of post-treatment's catalysts for the NOx (NO and NO2) reduction processes [27]. Thus, the control of PM's emission is necessary for diesel engine future developments. Generally, there are two steps of PM's treatment: filtration and regeneration [28]. Filtration consists of capturing soot in a Diesel Particulate Filter (DPF), followed by the regeneration which refers to the combustion of soot at relatively high temperature (around $600{ }^{\circ} \mathrm{C}[29]$ ) to avoid backpressure across the filter [25]. Alternatively, the Continuously Regenerating Trap (CRT) is able to continuously oxidize soot at lower temperature by using NO2 as a stronger oxidant instead of $\mathrm{O} 2$ [30,31]. On the other hand, NOx gases, which are also included in diesel exhaust in extremely small quantity, are highly toxic pollutants. NOx elimination is a technical problem because of mandatory requirements to add extra elements to aftertreatment systems, leading to an increase in overall cost of vehicles. A conventional diesel aftertreatment system combines both oxidation catalysts to oxidize trace substances (unburnt hydrocarbon, soot, $\mathrm{CO}, \mathrm{NO}$ ) and a consecutive NOx reduction catalyst. Many efforts have been made to reduce NOx in lean-rich exhaust cycles such as using lean NOx trap (LNT) or NOx storage/reduction (NSR) catalysts. An alternative way is to employ Selective Catalytic Reduction (SCR) by using extra reductants such as NH3 from injected urea solution [32]. These treatments are only productive in case of a large proportion of NO2 present in the exhaust gases [25,33,34]. Therefore, finding catalysts for soot combustion at low temperature while maintaining a high proportion of NO2 for further reduction processes is highly desirable. NOx-assisted soot oxidation is a simultaneous approach which involves NO to NO2 conversion and subsequent soot oxidation by the formed NO2 from the gas phase, at relatively low temperature [28].

Many works have investigated this reaction using noble metal catalysts, which are able to reduce the ignition temperature of soot oxidation (T10\% - temperature when $10 \%$ of soot is combusted) down to $370{ }^{\circ} \mathrm{C}$, depending on the operating conditions [28,35-38]. However, no high NO2 yields of the soot oxidation reaction have been reported whereas a high proportion of NO2 is beneficial for further NOx elimination processes (for instance, NH3-SCR). Obviously, the applications of noble metals are limited by their prohibitively expensive cost and strategic limitations of availability. Recently, Kim et al. suggested that perovskite $\mathrm{La} 0.9 \mathrm{Sr} 0.1 \mathrm{CoO} 3$ can be reasonably priced alternative since it can oxidize about $86 \%$ of $\mathrm{NO}$ at lower temperature $\left(300{ }^{\circ} \mathrm{C}\right)$ than noble metal rival Pt/A12O3 [39]. The study has been followed by other works on doped perovskites for low temperature soot oxidation such as LaMn0.9Co0.1O3 [40], BaMn0.7 Cu0.3O3 [41], $\mathrm{La} 0.9 \mathrm{ACoO} 3(\mathrm{~A}=\mathrm{Na}, \mathrm{K}$ and $\mathrm{Rb}$ ) [23], $\mathrm{La} 1-\mathrm{xBxO} 3(\mathrm{~B}=\mathrm{Ce}$ and $\mathrm{Sr}$ ) [27] and $\mathrm{BaCoO} 3-\lambda$ [42], focusing on the substitution of A- or B-sites to promote redox properties of perovskite oxides by generating either defective structure or multiple oxidation state cations. Furthermore, modified LaCoO3 is generally accepted as a highly active catalyst for NO oxidation $[20,43,44]$, whereas A12O3 supported oxides are reportedly able to catalyze NOx-assisted soot oxidation at relatively 
low temperature [45]. The combination of $\mathrm{Al}$ and $\mathrm{Co}$ in La-based perovskite oxides may be a promising approach for the NOx-assisted soot oxidation at low temperature. The present work investigates Co-doped $\mathrm{LaAlO} 3$ perovskite oxides for soot oxidation in the presence of NOx gases to correlate the catalytic activity with crystallinity, redox properties and the role of lattice oxygen.

\section{Experimental section}

\subsection{Catalyst preparation}

LaAl1-xCoxO3 were prepared by the sol-gel method with citric acid. $\mathrm{La}(\mathrm{NO} 3) 3 \cdot 6 \mathrm{H} 2 \mathrm{O}$ (SigmaAldrich,99\%), Al(NO3)3·9H2O (Sigma-Aldrich, 99\%), Co(NO3)2·6H2O (Sigma-Aldrich,99\%) were used as metal precursors and citric acid $\mathrm{C} 6 \mathrm{H} 8 \mathrm{O} 7 \cdot \mathrm{H} 2 \mathrm{O}$ as a gel-forming agent. Stoichiometric amounts of nitrate salts were dissolved in deionized water. A suitable amount of citric acid (citric acid:metal $=2 \mathrm{~mol} / \mathrm{mol}$ ) was added to the solution where the $\mathrm{pH}$ was kept at $7.5 \pm 0.5$ by dropwise addition of ammonia. The solution was stirred and evaporated at $80^{\circ} \mathrm{C}$ until the gel was formed. The gel was then kept at $150{ }^{\circ} \mathrm{C}$ for $3 \mathrm{~h}$ and at calcination temperature $\left(500,600\right.$ and $\left.700{ }^{\circ} \mathrm{C}\right)$ for $5 \mathrm{~h}$ with rampup of $5^{\circ} \mathrm{C} \mathrm{min}^{-1}$.

\subsection{Catalyst characterization}

The BET surface area was determined by N2 adsorption at $-196^{\circ} \mathrm{C}$ using a Micrometrics Tristar instrument with improved vacuum system. Samples were previously degassed at $250{ }^{\circ} \mathrm{C}$ until stable $10 \mathrm{~Pa}$ pressure was reached. XRD diffractograms were recorded using $\mathrm{Cu} \mathrm{K} \alpha(\lambda=0.15418$ $\mathrm{nm}$ ) radiation in a Bruker D8-Advance device. The reducibility of perovskite oxides was studied by H2-temperature programmed reduction (H2-TPR) using ThermoQuest TPDRO 1100 equipment equipped with TCD detector. The quartz tube reactor was loaded with about $50 \mathrm{mg}$ of sample and pretreated with $10 \mathrm{~mL} \mathrm{~min}{ }^{-1} \mathrm{~N} 2$ at $500{ }^{\circ} \mathrm{C}$ for $30 \mathrm{~min}$ and then cooled down to $50{ }^{\circ} \mathrm{C}$. Samples were then heated from room temperature to $950{ }^{\circ} \mathrm{C}$ with $5^{\circ} \mathrm{C} \mathrm{min}-1$ heating rate under 20 $\mathrm{mL} \min ^{-1} 5 \% \mathrm{H} 2 / \mathrm{Ar}$. O2-Temperature Programmed Desorption (O2-TPD) was conducted in the same instrument. The samples were previously treated under pure $\mathrm{O} 2$ flow $\left(40 \mathrm{~mL} \mathrm{~min}{ }^{-1}\right)$ at 600 ${ }^{\circ} \mathrm{C}$ for 30 min before cooling down to ambient temperature under $\mathrm{O} 2$ flow. The desorption was performed from room temperature to $950{ }^{\circ} \mathrm{C}$ under He flow $\left(20 \mathrm{~mL} \mathrm{~min}^{-1}\right)$ with heating rate of 5 ${ }^{\circ} \mathrm{C} \mathrm{min}^{-1}$. The NOx-TPD experiments were conducted in a flow-gas reactor system equipped with ABB Limas and Uras UV and NDIR analyzers to detect NO, NO2, N2O, CO, and CO2 gases separately. Catalysts were placed at the middle position of a $10 \mathrm{~mm}$ i.d. tubular reactor with thermocouple inserted into the catalytic bed to measure the reaction temperature. In a typical experiment, $200 \mathrm{mg}$ of sample was used. For the NOx desorption tests, NOx (250 ppm NO; 250 ppm NO2, balance $\mathrm{N} 2$; total flow $300 \mathrm{~mL} \mathrm{~min}^{-1}$ ) was adsorbed at $250{ }^{\circ} \mathrm{C}$ until stable concentration of NOx and cooled down to room temperature under $\mathrm{N} 2$ flow. The sample was then heated under $\mathrm{N} 2$ flow $\left(300 \mathrm{~mL} \mathrm{~min}{ }^{-1}\right)$ from room temperature to about $600{ }^{\circ} \mathrm{C}$ at $5{ }^{\circ} \mathrm{C} \min ^{-1}$. The XPS experiments were done as reported elsewhere [46]. Briefly, XPS analysis was carried out on an XPS PHI 5000 Versa probe apparatus, using the band-pass energy of $187.85 \mathrm{eV}$, a $45^{\circ}$ take off angle and a $100.0 \mu \mathrm{m}$ diameter X-ray spot size for survey spectra. High-resolution XP spectra were recorded in the following conditions: pass energy of $23.5 \mathrm{eV}$, resolution of $0.1 \mathrm{eV}$, and a step of $0.2 \mathrm{eV}$. Sample charging effects were eliminated by referring to the spectral line shift of the $\mathrm{C} 1 \mathrm{~s}$ binding energy (BE) value at $284.5 \mathrm{eV}$.

\subsection{Activity tests}


The NO oxidation tests were conducted in isothermal mode in the same system for NOx-TPD experiments mentioned above. The feed gas contained $650 \mathrm{ppm} \mathrm{NO}$ and $5 \% \mathrm{O} 2$ in N2 (total flow $254 \mathrm{~mL} \mathrm{~min}^{-1}$ ) and $200 \mathrm{mg}$ of catalyst was used. The temperature range for the oxidation was 150 $400{ }^{\circ} \mathrm{C}$. At each temperature, the stabilization time was about 20-30 min for reaching the steady state reaction in order to avoid the adsorption/desorption effect of NOx on catalysts. NO oxidation was also performed in the temperature ramping mode, in this case the reaction conditions matched those of the NOx-assisted soot oxidation: the feed gas contained $500 \mathrm{ppm} \mathrm{NO}$ and 4\% O2 in N2 with total flow $600 \mathrm{~mL} \mathrm{~min}{ }^{-1}$ and $200 \mathrm{mg}$ of catalyst with ramping rate $5{ }^{\circ} \mathrm{C} \mathrm{min}{ }^{-1}$. Besides the LaA11-xCoxO3 catalysts $\mathrm{Pt} / \mathrm{A} 12 \mathrm{O} 3$ with $5 \%$ Pt loading (Sigma-Aldrich 205974) was used as commercial reference.

The activity of the catalysts in NOx-assisted soot oxidation tests was determined by Temperature Programmed Reaction (TPR) with heating rate of $5^{\circ} \mathrm{C} \min ^{-1}$. The soot oxidation was studied by mixing $20 \mathrm{mg}$ of soot (Printex U, a carbon black used as model soot) with $180 \mathrm{mg}$ of catalyst or $\mathrm{SiC}$ for the reference non-catalytic test (catalyst:soot=9:1) in loose contact. Feed gas contained $500 \mathrm{ppm}$ of $\mathrm{NO}$ and $4 \%$ oxygen in a flow of $\mathrm{N} 2$ as balance gas, the total flow being $600 \mathrm{~mL} \mathrm{~min}^{-1}$. The tests were conducted between $200{ }^{\circ} \mathrm{C}$ and $700{ }^{\circ} \mathrm{C}$ with a ramp of $5{ }^{\circ} \mathrm{C} \mathrm{min}-1$. The soot conversion and $\mathrm{CO} 2$ selectivity were calculated as followed:

$$
\text { Soot conversion (\%) }=\frac{\sum_{0}^{t}\left(\mathrm{co}_{2}+\mathrm{co}\right)}{\left(\mathrm{co}_{2}+\mathrm{co}\right)_{\text {total }}} 100 \quad \mathrm{CO}_{2} \text { selectivity (\%) }=\frac{\sum_{0}^{t}\left(\mathrm{co}_{2}\right)}{\left(\mathrm{co}_{2}+\mathrm{co}\right)_{\text {total }}} 100
$$

\section{Results and discussion}

\subsection{Characterization}

\subsubsection{Structural properties}

X-ray diffraction patterns of all catalysts LaAl1-xCoxO3 ( $\mathrm{x}=0,0.25,0.5,0.75$ and 1$)$ calcined at $700{ }^{\circ} \mathrm{C}$ are shown in Fig. 1. All catalysts exhibit a well-crystallized perovskite phase, which is the only phase present from $\mathrm{x}=0$ to 0.5 and is accompanied in $\mathrm{LaA} 10.25 \mathrm{Co} 0.75 \mathrm{O} 3$ and $\mathrm{LaCoO} 3$ by two minor peaks at $2 \theta$ of about 36.7 and $28.1^{\circ}$, which belong respectively to Co3O4 and La2O3. The perovskite phase presents symmetric diffraction peaks in the case of LaAlO3, whereas peak splitting is observed with increasing cobalt. Rietveld analysis has been conducted on all catalysts calcined at $700{ }^{\circ} \mathrm{C}$ to understand the lowering of symmetry with Co-doping. The refinement was done with the Thompson-Cox-Hastings pseudo-Voigt peak profile and two space groups: rhombohedral R-3c and cubic Pm-3 m. The refinement data, reported in Table 1, confirm the change of perovskite symmetry with the composition, LaAlO3 being cubic and all other samples being rhombohedral. Interestingly, all samples would be expected presenting R-3c space group at room temperature [47]. Rhombohedral perovskite normally evolves towards cubic structure when the octahedral tilting is reduced at higher temperature. LaAlO3 is normally rhombohedral at room temperature, reaching space group Pm-3m at nearly $530{ }^{\circ} \mathrm{C}[47,48]$. The presence of cubic phase at room temperature is probably due to a metastability effect. Substituted LaAl perovskites remain rhombohedral also at very high temperature and, in the case of $\mathrm{LaCoO} 3$, the rhombohedral structure is also stable above $970{ }^{\circ} \mathrm{C}[48,49]$. In the case of solid solutions intermediate between $\mathrm{LaAlO} 3$ and $\mathrm{LaCoO} 3$, Aswin et al. observed that the rhombohedral phase was accompanied by a 


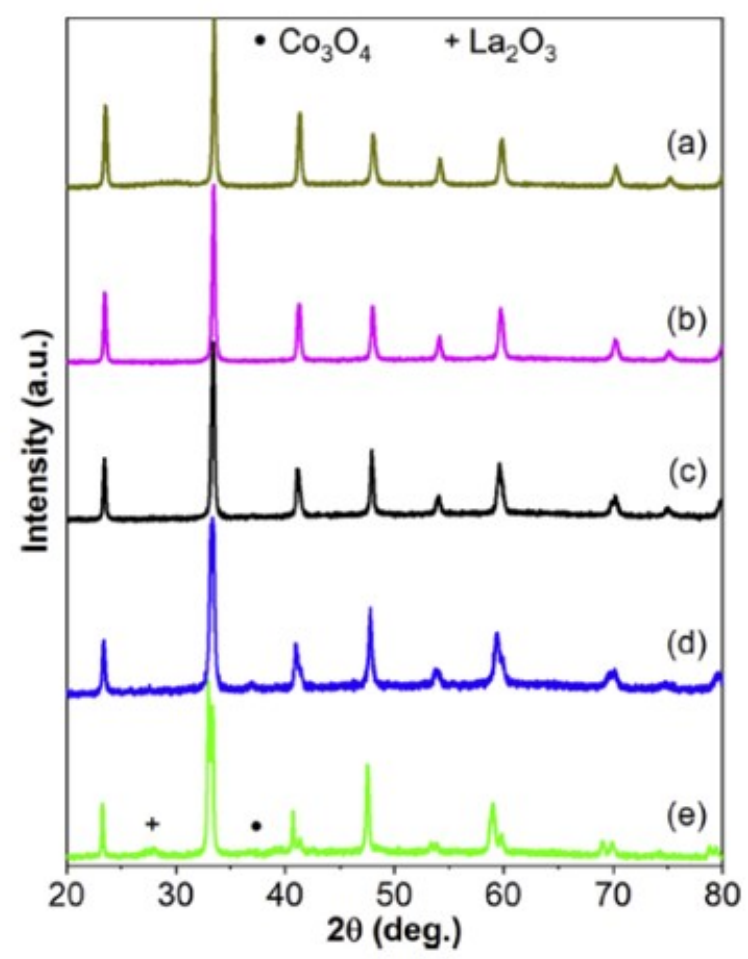

Fig. 1. X-Ray diffractions of LaAl1-xCoxO3 calcined at $700{ }^{\circ} \mathrm{C}$ : (a) $x=0$; (b) $x=0.5$; (c) $x=0.5$; (d) $x=0.75$; (e) $x=1$.

secondary monoclinic perovskite phase [50]. No monoclinic phase was observed in our samples. It is tempting to assume that the presence of such a phase is a secondary result of sintering at $1030{ }^{\circ} \mathrm{C}$ in the preparation of Aswin et al.

The volume of the formula units $\mathrm{LaAll-x \textrm {CoxO } 3}$ calculated from the cell parameters, taking into account $Z=1$ for $P m-3 m$ and $Z=6$ for $R-3 c$ space groups, are reported in Table 1 and highlighted in Fig. 2a. They show a systematic increase of volume from $\mathrm{LaAlO} 3$ to $\mathrm{LaCoO} 3$ once the $\mathrm{R}-3 \mathrm{c}$ symmetry is established, indicating that $\mathrm{Co}$ is well incorporated inside the perovskite framework. In fact, trivalent Co is larger than Al3+ [51], so the substitution of Al by Co tends to expand the unit cell.

\begin{tabular}{lllll}
\hline $\begin{array}{l}\mathrm{LaAl}_{1 \cdot x} \mathrm{Co}_{x} \mathrm{O}_{3} \\
(\mathrm{x})\end{array}$ & $\begin{array}{l}\text { Space } \\
\text { group }\end{array}$ & a $(\AA)$ & c $(\AA)$ & $\begin{array}{l}\text { Formula unit volume } \\
\left(\AA^{3}\right)\end{array}$ \\
\hline 0 & Pm-3m & $3.7927(1)$ & - & $54.556(2)$ \\
0.25 & $\mathrm{R}-3 \mathrm{c}$ & $5.3673(2)$ & $13.117(1)$ & $54.542(3)$ \\
0.5 & $\mathrm{R}-3 \mathrm{c}$ & $5.3772(2)$ & $13.101(1)$ & $54.882(1)$ \\
0.75 & $\mathrm{R}-3 \mathrm{c}$ & $5.4046(2)$ & $13.108(1)$ & $55.263(3)$ \\
1 & R-3c & $5.4427(2)$ & $13.126(1)$ & $56.122(3)$ \\
\hline
\end{tabular}

Table 1.

Refinement parameters of LaAl1-xCoxO3 calcined at $700{ }^{\circ} \mathrm{C}$.
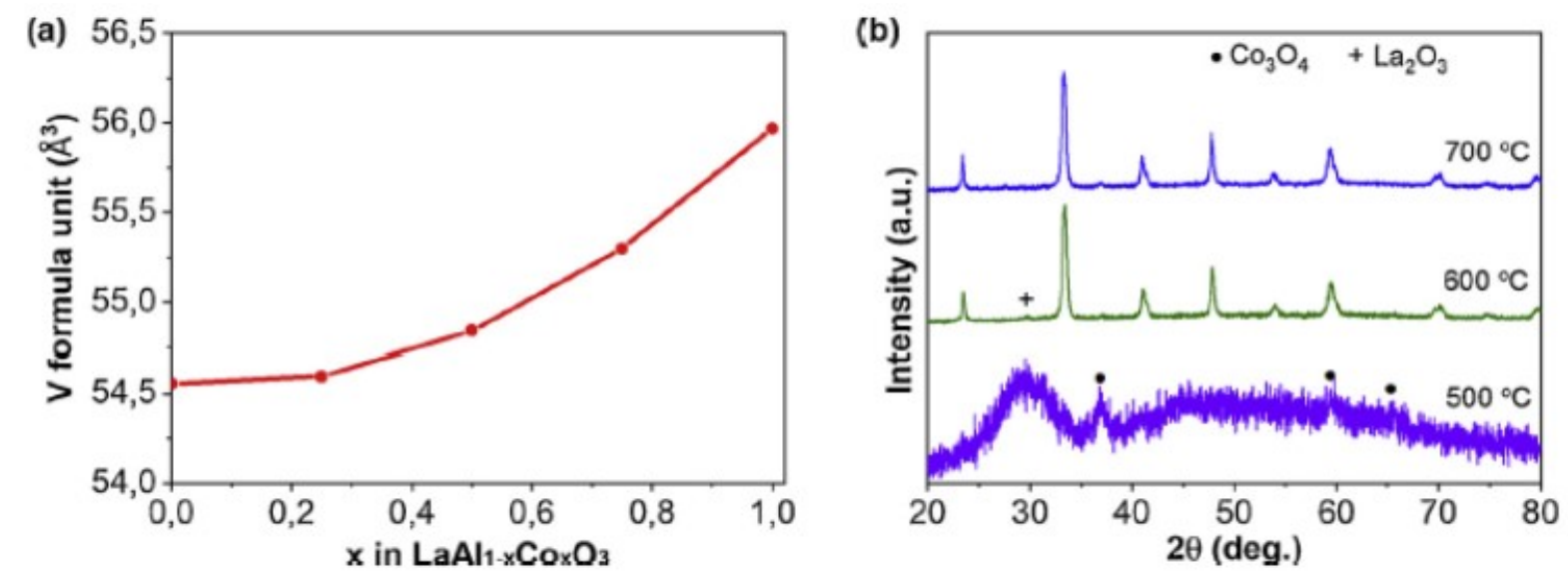

Fig. 2. (a) Volume of the formula units LaAl1-xCoxO3 as a function of the cobalt fraction; (b) diffraction patterns of LaAl0. 25Co0.75O3 calcined at different temperatures. 
The effect of calcination temperature on the formation of the perovskite phase is highlighted in Fig. $2 \mathrm{~b}$, in which the diffraction patterns of LaA10.25Co0.75O3 calcined at 500,600 and $700{ }^{\circ} \mathrm{C}$ are shown. The diffraction pattern at $500{ }^{\circ} \mathrm{C}$ present no perovskite peaks but exhibits broad bands of $\mathrm{Co} 3 \mathrm{O} 4$ and $\mathrm{La} 2 \mathrm{O} 3$ phases. Evaluation of the peaks of these phases by the Scherrer method suggests sizes of $27 \mathrm{~nm}$ for $\mathrm{Co} 3 \mathrm{O} 4$ and $2.6 \mathrm{~nm}$ for $\mathrm{La} 2 \mathrm{O} 3$, a signature of nano-crystalline form for this last phase. At $600{ }^{\circ} \mathrm{C}$, the perovskite structure emerges beside traces of $\mathrm{La} 2 \mathrm{O} 3$ phase, better crystallized than at $500{ }^{\circ} \mathrm{C}$. La2O3 disappears altogether at a calcination temperature of $700{ }^{\circ} \mathrm{C}$, leaving perovskite as the only crystalline phase.

The textural properties of LaAl1-xCoxO3 calcined at $700{ }^{\circ} \mathrm{C}$ are listed in Table 2 . The average crystallite size of LaAll-xCoxO3 is calculated from the Rietveld refinement by the WilliamsonHall method. Crystallite size dc slightly varies around $30 \mathrm{~nm}$ for $\mathrm{x}=0$ to 0.75 , before jumping up for the total introduction of cobalt. The surface areas of all samples, measured by N2 sorption, are between 10-15 $\mathrm{m}^{-1} \mathrm{~g}^{-1}$, as expected for samples annealed at high temperature [52]. It can be observed that the observed variation in crystallite size does not correspond to any equivalent change in surface area. Indeed, taking into account the density of the perovskite, the observed surface areas correspond to grain size between 60 and $80 \mathrm{~nm}$, in good agreement only with the crystallite size of $\mathrm{LaCoO} 3$. It is tempting to advance the hypothesis that, in the case of all other samples, the $30 \mathrm{~nm}$ crystallites are the result of splitting of larger grains during the thermal treatment.

\begin{tabular}{llll}
\hline $\mathrm{LaAl}_{1, \alpha} \mathrm{Co}_{\mathrm{x}} \mathrm{O}_{3}(\mathrm{x})$ & $\mathrm{d}_{\mathrm{e}}(\mathrm{nm})$ & $\mathrm{S}_{\mathrm{aEr}}\left(\mathrm{m}^{2} \mathrm{~g}^{-1}\right)$ & $\mathrm{V}_{\mathrm{p}}\left(\mathrm{cm}^{3} \mathrm{~g}^{-1}\right)$ \\
\hline 0 & 30.5 & 14.4 & 0.10 \\
0.25 & 32.1 & 11.4 & 0.09 \\
0.50 & 36.8 & 11.6 & 0.09 \\
0.75 & 28.7 & 13.1 & 0.08 \\
1.0 & 73.7 & 12.3 & 0.08 \\
\hline
\end{tabular}

Table 2. Textural properties of LaAl1-xCoxO3 calcined at 700 ${ }^{\circ} \mathrm{C}$.

\subsubsection{Redox properties}

Fig. 3 summarizes the H2-TPR profiles of LaAl1-xCoxO3 $(x=0,0.25,0.5,0.75,1)$ calcined at 700 ${ }^{\circ} \mathrm{C}$ and LaAl0.25Co0.75O3 calcined at 500,600 and $700{ }^{\circ} \mathrm{C}$. In the literature, the reduction of $\mathrm{Co}^{3+}$ in $\mathrm{LaCoO} 3$ was generally proposed by two different pathways, implying one or two steps. In the two-steps route, $\mathrm{Co}_{3}^{+}$is converted to $\mathrm{Co} 0$ via $\mathrm{Co}^{2+}$ in two distinguished temperature regions at around $420{ }^{\circ} \mathrm{C}$ for $\mathrm{Co}^{3+}$ to $\mathrm{Co}^{2+}$ and $550{ }^{\circ} \mathrm{C}$ for $\mathrm{Co}^{+}$to $\mathrm{Co}^{0}$ with the formation of intermediate brownmillerite $\mathrm{LaCoO} 2.5$ [16,53-57]. This two-steps mechanism should be confirmed by the area ratio of the first peak to the second one of 1:2 [58]. However, the $\mathrm{H} 2$ consumption in the hightemperature reduction region is usually found lower than expected $[44,55,59]$, suggesting that $\mathrm{Co}^{0}$ might be partially formed in the first stage at lower temperature $[55,60]$. Indeed, the $\mathrm{Co}^{3+}$ reduction was also proposed as one-step mechanism, in which $\mathrm{Co} 0$ can be produced directly from $\mathrm{Co}^{3+}$ with the formation of oxygen-deficient compound $\mathrm{LaCoO} 3-\mathrm{y}$, bypassing the $\mathrm{Co}^{2+}$ species [60], and splitting of the reduction peak can be attributed to different structural Co3+ species related to the distortion of perovskite structure and oxygen defects [61].

The TPR profile of the as-prepared $\mathrm{LaCoO} 3$ reveals two separate peaks with maxima at ca. 395 and $580{ }^{\circ} \mathrm{C}$ (Fig. 3a). The H2-consumption, reported in Table 3, corresponds to a $1.5 \mathrm{H} 2 / \mathrm{Co}$ ratio, indicating that all $\mathrm{Co} 3+$ has been reduced to $\mathrm{Co}$. The $\mathrm{H} 2$-consumption ratio between the first and second reduction peaks is $1.04 / 1$, indicating that the first peak does not correspond only to the reduction of $\mathrm{Co}^{3+}$ to $\mathrm{Co}^{2+}$ but includes some further reduction of $\mathrm{Co}^{2+}$. The mechanism of reduction 

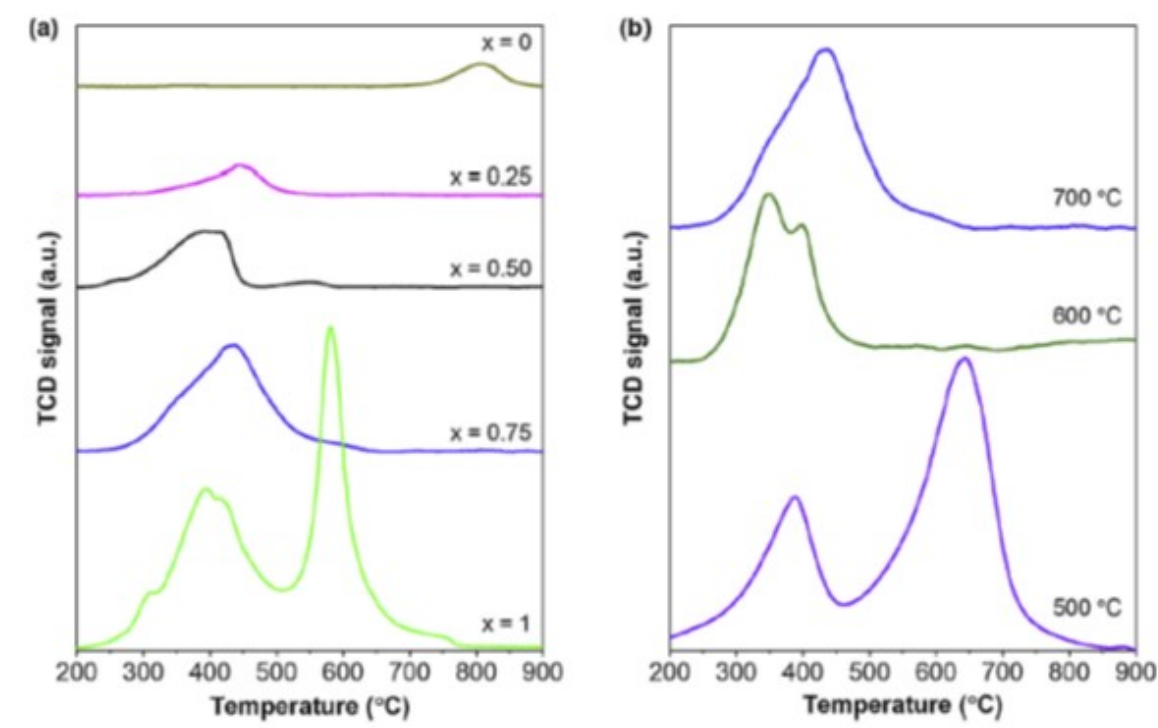

Fig. 3.

H2-TPR profiles of the samples LaAl1-xCoxO3 calcined at $700{ }^{\circ} \mathrm{C}($ a) ; LaAl0.25Co0.75O3 calcined at different temperatures (b).

\begin{tabular}{|c|c|c|c|c|}
\hline Catalysts & $\mathrm{x}$ & $\begin{array}{l}\text { Peak temperature } \\
\text { ('C) }\end{array}$ & $\begin{array}{l}\mathrm{H}_{2} \text {-consumption } \\
\left(\mu \mathrm{mol} \mathrm{g}^{-1}\right)\end{array}$ & $\begin{array}{l}\mathrm{H}_{2} / \mathrm{Co} \\
\mathrm{mol} / \mathrm{mol}\end{array}$ \\
\hline $\mathrm{LaAlO}_{3}$ & 0.00 & - & - & - \\
\hline $\mathrm{LaAl}{ }_{275} \mathrm{CO}_{025} \mathrm{O}_{3}$ & 0.25 & 445 & 1202 & 1.07 \\
\hline $\mathrm{LaAb} \mathrm{so}_{0} \mathrm{Co}_{0.50} \mathrm{O}_{3}$ & 0.50 & 394 & 2909 & 1.34 \\
\hline $\mathrm{LaAl}_{0.25} \mathrm{Co}_{0.75} \mathrm{O}_{3}$ & 0.75 & 437 & 4909 & 1.56 \\
\hline $\mathrm{LaCoO}_{3}$ & 1.00 & 395,580 & 6379 & 1.57 \\
\hline
\end{tabular}

Table 3.

H2-consumption of LaAl1-xCoxO3 with different composition.

seems hence to be a mixed one-step and two-steps process. The first reduction peak presents several components: the small shoulder located at $310^{\circ} \mathrm{C}$ can be ascribed to microcrystalline part or chemisorbed oxygen in the catalyst surface [20]. The two overlapping components at 391 and $418{ }^{\circ} \mathrm{C}$ probably include the formation of $\mathrm{Co}^{0}$ at relatively low temperature $[55,60]$.

When Al partially replaces $\mathrm{Co}$ in $\mathrm{LaCoO} 3$, the H2-TPR profiles of $\mathrm{LaAl1}-\mathrm{xCoxO} 3$ follow the onestep reduction mechanism from around $210{ }^{\circ} \mathrm{C}$ to $600{ }^{\circ} \mathrm{C}$. The $\mathrm{H} 2 / \mathrm{Co}$ ratio (Table 3) is close to the values of total reduction for $\mathrm{LaAl} 10.25 \mathrm{Co} 0.75 \mathrm{O} 3$, indicating that $\mathrm{Co}^{3+}$ is completely reduced to $\mathrm{Co}^{0}$ up to around $600{ }^{\circ} \mathrm{C}$. This suggests that, in bimetallic Al-Co perovskites, $\mathrm{Co}^{3+}$ can be reduced to metallic species at low temperature without any clear intermediate formation of $\mathrm{Co}^{2+}$, and the asymmetry of peak shape may be due to variously distinct $\mathrm{Co}^{3+}$ species in perovskite lattice [61]. $\mathrm{LaA} 10.5 \mathrm{Co} 0.5 \mathrm{O} 3$ and $\mathrm{LaA} 10.75 \mathrm{Co} 0.25 \mathrm{O} 3$, the most Al-rich mixed samples, present a $\mathrm{H} 2-$ consumption lower than the value expected for complete reduction of $\mathrm{Co}^{3+}$ (Table 3 ). This effect could be attributed to a lower than expected average oxidation state of cobalt, probably related to cation vacancies. In the case of the Co-free LaAlO3, a small peak observed above $800{ }^{\circ} \mathrm{C}$ is not related to reduction phenomena but corresponds to $\mathrm{CO} 2$ release from decomposition of carbonate species from the surface of this highly basic solid.

Fig. 3b shows H2-TPR profiles of LaA10.25Co0.75O3 calcined at 500, 600 and $700{ }^{\circ} \mathrm{C}$. The sample annealed at $500{ }^{\circ} \mathrm{C}$ exhibits two peaks at 388 and $646^{\circ} \mathrm{C}$. The first peak closely correspond to the expected temperature for reduction of the $\mathrm{Co} 3 \mathrm{O} 4$ phase observed in the sample [62]. The second peak does not correspond to a reduction peak but it is at the temperature expected for the decarbonation of the carbonate species at the surface of the extremely dispersed La2O 3 evidenced by the XRD pattern [63]. LaA10.25Co0.75O3 calcined at $600{ }^{\circ} \mathrm{C}$ reveals two overlapped peaks at 
350 and $398{ }^{\circ} \mathrm{C}$. This corresponds to the formation of $\mathrm{Co} 0$ by reduction of perovskite LaAl0.25Co0.75O3 at a temperature nearly $90{ }^{\circ} \mathrm{C}$ lower than in the case of the same material calcined at $700{ }^{\circ} \mathrm{C}$. This may be linked with lower surface area, narrower crystal size distribution and higher crystal size with higher calcination temperature, which leads to more diffusional resistance [24].

It is generally accepted that perovskite $\mathrm{LaCoO} 3$ exhibits two type of desorbed oxygen. The $\alpha-$ oxygen, which is desorbed below $750{ }^{\circ} \mathrm{C}$, is usually ascribed to oxygen weakly bound to perovskite surface. $\beta$-oxygen is lattice oxygen which diffuses from bulk and it is considered as an indicator of oxygen mobility in the structure $[54,59,64,65]$. The latter species can come from inner bulk oxygen vacancies or can be directly associated with the B-site cation reduction in the perovskite oxide framework [56]. $\mathrm{LaCoO} 3$ shows two desorption peaks at around $650{ }^{\circ} \mathrm{C}$ and $827^{\circ} \mathrm{C}$, probably corresponding to $\alpha$ - and $\beta$-oxygen, respectively (Fig. 4). LaCoO3 releases $77.5 \mu \mathrm{mol} \mathrm{g}^{-1}$ of $\beta$-oxygen (nearly $2 \%$ of bulk oxygen), as a result of $\mathrm{Co}^{3+}$ to $\mathrm{Co}^{2+}$ reduction and anion vacancy generation $[20,64]$. The amount of $\beta$-oxygen release from $\mathrm{LaCoO} 3$ and the desorption temperature are comparable with the results of other groups [66,67]. Decreasing the cobalt fraction $\mathrm{x}$ from 1 to 0.75 significantly raises the quantity of $\beta$-oxygen, LaAl0.25Co0.75O3 releasing $158.1 \mu \mathrm{mol} \mathrm{g}^{-1}$ at a lower desorption temperature of $849^{\circ} \mathrm{C}$. The oxygen species in LaAl0.25Co0.75O3 occupies almost $3.7 \%$ of total oxygen anion in perovskite, revealing the highest oxygen mobility among the studied samples.

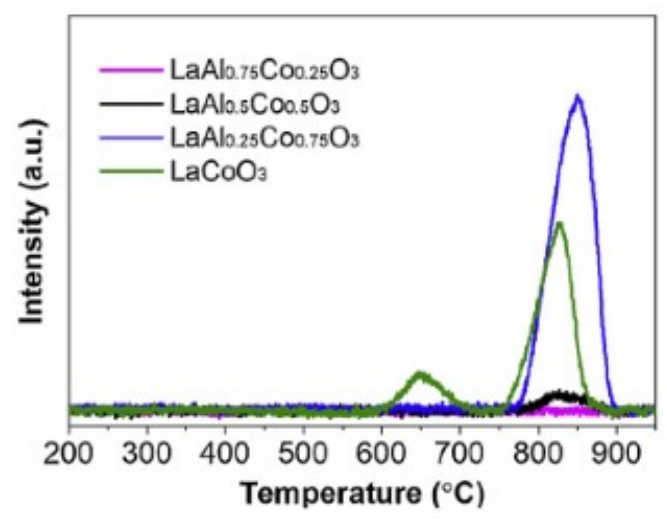

Fig. 4. O2-TPD profiles of LaCo1-xAlxO3 samples calcined at $700{ }^{\circ} \mathrm{C}$.

It should be noticed that Royer et al. suggested that $\beta$ oxygen is likely to originate from grain boundaries between two neighbor crystal domains due to higher oxygen diffusivity within boundaries than bulk, and the feature was significantly enhanced by substituting $20 \%$ of $\mathrm{Co}$ by $\mathrm{Fe}$ to form $\mathrm{LaCo} 0.8 \mathrm{Fe} 0.2 \mathrm{O} 3$ [66]. Therefore, the highest amount of lattice oxygen for LaAl0.25Co0.75O3 may be related to the smallest crystallite size among the studied samples. For further decrease of cobalt content, the oxygen evolution dramatically drops to $9.1 \mu \mathrm{mol} \mathrm{g}{ }^{-1}$ when $50 \%$ of Co is replaced by $\mathrm{Al}$ and no $\beta$-oxygen is measured when only $25 \%$ cobalt is left (Table 4). LaAl0.75Co0.25O3 exhibits no oxygen evolution during the experiment, as it is the case for $\mathrm{LaAlO} 3$ due to non-reducibility of aluminum cations. The decrease of $\beta$-oxygen with the increase of cobalt content closely matches the decrease of H2-consumption in H2-TPR and confirms that the cobalt-richest samples present abundant cation vacancies and a lower than expected cobalt oxidation state.

\begin{tabular}{llll}
\hline Samples & $\begin{array}{l}\beta-\mathrm{O}_{2} \text {-desorption } \\
\left(\mu \mathrm{mol} \mathrm{g}{ }^{-1}\right)\end{array}$ & $\begin{array}{l}\text { O-percentage } \\
(\mathrm{mol} \%)\end{array}$ & $\begin{array}{l}\text { Temperature } \\
\left({ }^{\circ} \mathrm{C}\right)\end{array}$ \\
\hline $\mathrm{LaAl}_{0.75} \mathrm{Co}_{0.25} \mathrm{O}_{3}$ & - & - & - \\
$\mathrm{LaAl}_{0.50} \mathrm{Co}_{0.50} \mathrm{O}_{3}$ & 9.1 & 0.2 & 827 \\
$\mathrm{LaAl}_{0.25} \mathrm{Co}_{0.75} \mathrm{O}_{3}$ & 158.1 & 3.7 & 849 \\
$\mathrm{LaCoO}_{3}$ & 77.5 & 1.9 & 827 \\
\hline
\end{tabular}

Table 4. Calculated quantity of desorbed oxygen of LaAl1$x \mathrm{CoxO} 3$ obtained by integration of O2-TPD profiles. 


\subsubsection{Surface properties}

The Fig. 5a shows XPS profiles of $\mathrm{LaAl1}-\mathrm{xCoxO} 3$ ( $\mathrm{x}=0,0.25,0.5$ and 0.75 ) with $\mathrm{Co} 2 \mathrm{p} 3 / 2$ and $2 \mathrm{p} 1 / 2$ binding energy at 780-780.4 $\mathrm{eV}$ and $795.4 \mathrm{eV}$ respectively, both ascribed to Co3+ species [67,68]. Moreover, distorted 2p3/2 Co pattern is distinctive for $\mathrm{Co}^{3+}$ species [69], with a similar gap between $2 \mathrm{p} 1 / 2-2 \mathrm{p} 3 / 2$ of $15.4 \mathrm{eV}$ [70] and no $\mathrm{Co}^{2+}$ shake up peaks at 785-788 eV [69] [71], suggesting that mainly $\mathrm{Co}^{3+}$ species can be detected at the surface of the prepared samples. However, the satellite signal at $790.2 \mathrm{eV}$ and broadening region at about $805 \mathrm{eV}$ can be seen in LaAl0.5Co0.5O3, and more pronounced in the sample with more cobalt: LaA10.25Co0.75O3. This
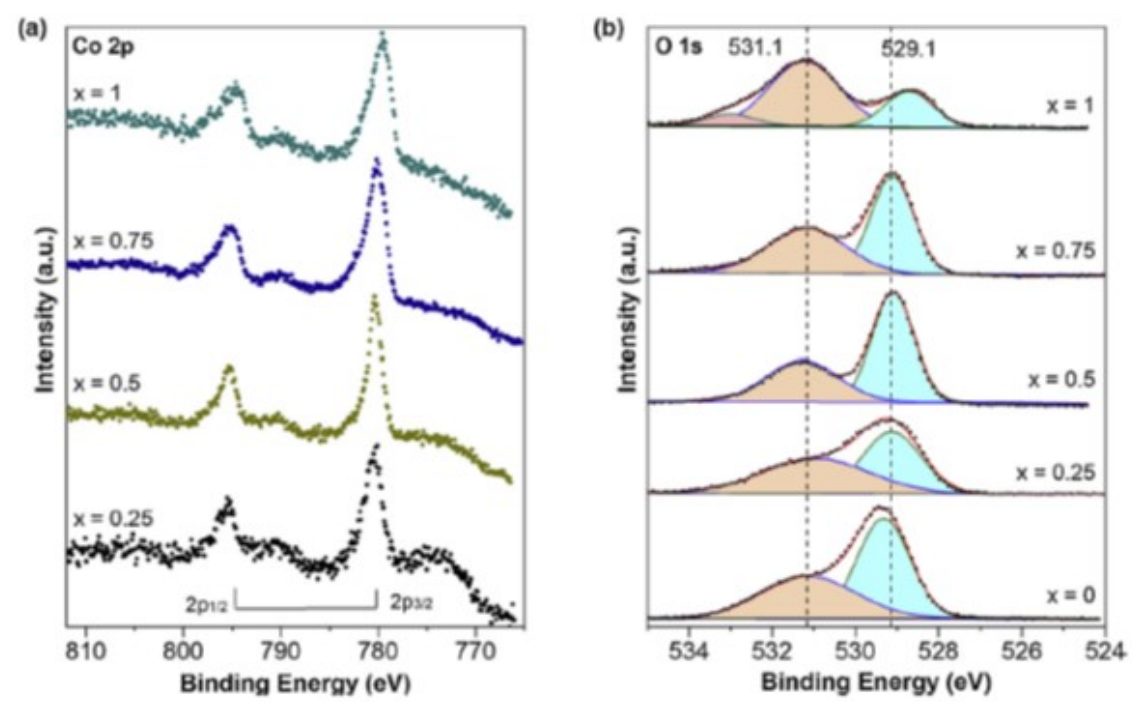

Fig. 5. XPS spectra of Co $2 p$ (a) and $O$ ls (b) of LaAl1- $x$ CoxO3 $(x=0,0.25$, $0.5,0.75,1)$.

Table 5. Relative abundances of oxygen species derived from the deconvolution of $O$ Is XPS spectra and Co/Al surface ratio.

\begin{tabular}{|c|c|c|c|c|c|c|c|}
\hline \multirow[t]{2}{*}{ Sample } & \multirow[t]{2}{*}{$(\mathrm{Co} / \mathrm{Al})_{\operatorname{surf}}$} & \multirow{2}{*}{$\begin{array}{l}\text { Co } 2 \mathrm{p}_{3 / 2} \\
\mathrm{BE}(\mathrm{eV})\end{array}$} & \multicolumn{2}{|l|}{$\mathrm{O}_{\text {ads }}$} & \multicolumn{2}{|l|}{$\mathrm{O}_{\text {lat }}$} & \multirow[t]{2}{*}{$\mathrm{O}_{\mathrm{ads}} / \mathrm{O}_{\mathrm{lat}}$} \\
\hline & & & $\mathrm{BE}(\mathrm{eV})$ & $\%$-atom & $\mathrm{BE}(\mathrm{eV})$ & $\%$-atom & \\
\hline $\mathrm{LaAlO}_{3}$ & 0 & - & 531.1 & 43.5 & 529.3 & 56.5 & 0.77 \\
\hline $\mathrm{LaAl}_{0.75} \mathrm{Co}_{0.25} \mathrm{O}_{3}$ & 0.4 & 780.4 & 531.2 & 44.4 & 529.2 & 55.6 & 0.80 \\
\hline $\mathrm{LaAl}_{0.5} \mathrm{Co}_{0.5} \mathrm{O}_{3}$ & 0.6 & 780.4 & 531.3 & 39.4 & 529.1 & 60.6 & 0.65 \\
\hline $\mathrm{LaAl}_{0.25} \mathrm{Co}_{0.75} \mathrm{O}_{3}$ & 3.2 & 780.0 & 531.1 & 42.9 & 529.1 & 57.1 & 0.75 \\
\hline $\mathrm{LaCoO}_{3}$ & - & 779.5 & 531.2 & 66.2 & 528.7 & 25.4 & 260 \\
\hline
\end{tabular}

profile is reported for $\mathrm{Co} 3 \mathrm{O} 4$ [72], indicating that there may be some cobalt oxides not incorporated in perovskite structure when more than $50 \%$ of $\mathrm{Al}$ is replaced by $\mathrm{Co}$, which is in agreement with XRD profiles. Table 5 listed the ratios of surface $\mathrm{Co} / \mathrm{Al}$ which increase from 0.4 for $\mathrm{LaAl} 10.75 \mathrm{Co} 0.25 \mathrm{O} 3$ to 3.2 for $\mathrm{LaAl} 0.25 \mathrm{Co} 0.75 \mathrm{O} 3$. This ratio for $\mathrm{LaAl} 10.75 \mathrm{Co} 0.25 \mathrm{O} 3$ is higher than its bulk composition (0.33) by around $20 \%$ and the surface is slightly enriched with Co. By contrast, LaAl0.5 $\mathrm{Co} 0.5 \mathrm{O} 3$ has surface Co lower than in the bulk composition: 0.6 in comparison with theoretical 1.0.

The O 1s XPS spectra are deconvoluted to two oxygen species: peaks at $529.1-529.3 \mathrm{eV}$ are characteristic of surface lattice oxygen (denoted as Olat) and signals at 531.1-531.3 eV can be ascribed to oxygen adsorbed on perovskite surface (denoted as Oads) [73,74] (Fig. 5b). Concerning the $\mathrm{LaCoO} 3$ sample, its $\mathrm{O}$ 1s curve was satisfactorily curve-fitted by using 3 peaks. Besides the two components previously described, the signal at higher $\mathrm{BE}(533 \mathrm{eV})$ has been assigned to $\mathrm{O}$ species in some segregated oxide phases. Such an assignment is in agreement with the XRD pattern 
of the sample, in which the main peak of the La2O3 and Co3O4 phases was detected (see Fig. 1). The ratios Oads/Olat of LaAl1-xCoxO3 with $\mathrm{x}=0,0.25,0.5$ and 0.75 are 0.77, 0.80, 0.65 and 0.75, respectively (Table 5). These four samples, with similar surface area, show Oads/Olat ratios in the same range, whereas the $\mathrm{LaCoO} 3$ sample, with much lower surface area, shows a much higher Oads/Olat surface ratio. These data clearly indicate that the oxygen distribution at the surface in non-reactive conditions poorly reflects the bulk mobility of oxygen as revealed by H2-TPR or O2desorption experiments. The quantity of Oads is relatively correlated to surface area values which are similar for $\mathrm{LaAlO} 3$.

\subsubsection{NOx-temperature programmed desorption}

For the NOx-TPD measurement, the samples were adsorbed by equal quantities of NO and NO2 (about $250 \mathrm{ppm}$ of each balanced by N2) at $250{ }^{\circ} \mathrm{C}$ until the saturation, cooled down under N2, and followed by heating up under $\mathrm{N} 2$ atmosphere with a rate of $5{ }^{\circ} \mathrm{C} \mathrm{min}^{-1}$. Fig. 6 a reveals the NOx-TPD profiles of LaAl1-xCoxO3 (x up to 0.75), while a similar figure for LaCoO3 is plotted in Fig. 6c. The first small NOx desorption can be ascribed to physically adsorbed species which peaks at about $150{ }^{\circ} \mathrm{C}$ for $\mathrm{LaAlO} 3$, and decreases by around $60^{\circ} \mathrm{C}$ when $\mathrm{Al}$ is substituted by Co. It is reported that the NOx desorption below $250{ }^{\circ} \mathrm{C}$ is mostly related to B-site of perovskite, while at high temperature the basic A-site may take a role [44]. The adsorbed species is reportedly in dependence with adsorption temperature [75]. When NOx is adsorbed below $250{ }^{\circ} \mathrm{C}$, it is mainly stored as nitrite species, which can convert Fig. 4. O2-TPD profiles of LaCo1-xAlxO3 samples calcined at $700{ }^{\circ} \mathrm{C}$. into nitrate at higher adsorption temperature [75]. In contrast, at high temperatures NOx can be released by the nitrate decomposition followed by the oxides formation and the destruction of perovskite structure. [42]. It is also suggested that at low adsorption temperature NOx is stored as chemisorbed NOx and converted to nitrate by interaction with surface hydroxyl groups [76]. This chemisorbed species may be unstable, and it can be released during TPD experiment up to $350{ }^{\circ} \mathrm{C}$.
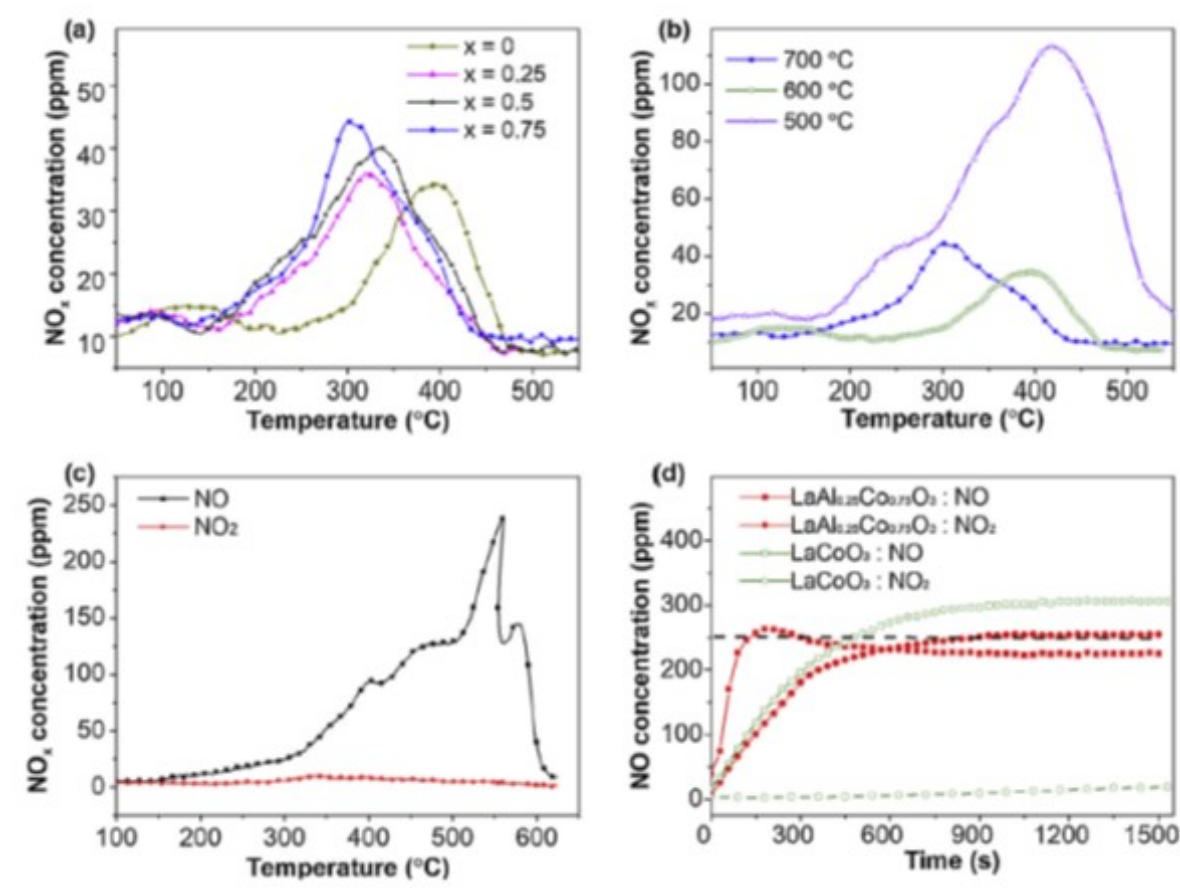

Fig. 6.

NOx desorption curves of (a) LaCo1-xAlxO3 calcined at $700{ }^{\circ} \mathrm{C}$ and (b) LaAl0.25Co0.75O3 calcined at different temperatures; (c) NOx desorption of $\mathrm{LaCoO} 3$ at $250{ }^{\circ} \mathrm{C}$ with time $(250$ ppm of NOx and $250 \mathrm{ppm}$ of NO2 balance in N2; $\left.250{ }^{\circ} \mathrm{C}\right) ; \quad$ (d) NOx adsorption on $\mathrm{LaCoO} 3$ and LaAlO.25Co0.75O3 at $250{ }^{\circ} \mathrm{C}$. 
Generally, NO2 is desorbed at a lower temperature in all studied samples compared to NO [77], and its desorption temperature drops with increased Co doping, from $351{ }^{\circ} \mathrm{C}$ for LaAlO3 to 275 ${ }^{\circ} \mathrm{C}$ for LaA10.25Co0.75O3, and almost disappears in case of LaCoO3 (Table 6). The quantity of desorbed gases is similar in all cases except LaCoO3, varying from around 53 to $75 \mu \mathrm{mol} \mathrm{g} \mathrm{g}^{-1}$. The values partially depend on the surface area which may be not promoted by high calcination temperature of perovskite oxides. Furthermore, deficient perovskites favor NO adsorption on oxygen vacancies before oxidizing to $\mathrm{NO} 2[43,78]$ which may not be found in our compounds persevering charge neutrality.

\begin{tabular}{|c|c|c|c|c|c|}
\hline \multirow[t]{2}{*}{ Catalysts } & \multicolumn{2}{|l|}{$\mathrm{NO}_{2}$} & \multicolumn{2}{|l|}{ No } & \multirow{2}{*}{$\begin{array}{l}\text { Total } \\
\left(\mu \mathrm{mol} \mathrm{g}^{-1}\right)\end{array}$} \\
\hline & $\begin{array}{l}\text { Amount } \\
\left(\mathrm{gmd} \mathrm{g}^{-1}\right)\end{array}$ & $\begin{array}{l}T_{\max } \\
(\mathrm{C})\end{array}$ & $\begin{array}{l}\text { Amount } \\
\left(\mu \mathrm{mol} \mathrm{g}^{-1}\right)\end{array}$ & $\begin{array}{l}T_{m=} \\
(' C)\end{array}$ & \\
\hline LaAlo, & 26.8 & 351 & 26.2 & 412 & $\mathbf{5 3 . 0}$ \\
\hline $\mathrm{LaAl}_{0.5} \mathrm{CO}_{0.25} \mathrm{O}_{3}$ & 27.8 & 294 & 25.8 & 347 & 52.9 \\
\hline $\mathrm{LaAl}_{0} \mathrm{CO}_{0} \mathrm{O}_{3}$ & 36.5 & 289 & 38.7 & 350 & 75.2 \\
\hline $\mathrm{LaAl}_{02 \mathrm{~s}} \mathrm{CO}_{a r s} \mathrm{O}_{3}$ & 24.7 & 275 & 36.3 & 320 & 61.0 \\
\hline $\mathrm{LaCoO}_{3}$ & - & - & 410.2 & 558 & 411.7 \\
\hline
\end{tabular}

Table 6. Desorbed NOx quantity and relative desorption temperature of LaAl1-xCoxO3.

NO desorption temperature has the same trend of NO2 but at a higher temperature. It decreases with Co content from $412{ }^{\circ} \mathrm{C}$ for $\mathrm{LaAlO} 3$ to a similar range of $347-350{ }^{\circ} \mathrm{C}$ for both LaA10.75Co0.25O3 and LaA10.5Co0.5O3, and drops to the minimum of $320{ }^{\circ} \mathrm{C}$ for LaA10.25Co0.75O3. Surprisingly, a decrease in Al quantity weakens the bond with acidic NOx, leading to lower desorption temperature. The introduction of Co may induce some modifications of the perovskite surface which leads to variation in desorption temperature of NOx [44]. It is reported that calcination temperature up to $1000{ }^{\circ} \mathrm{C}$ induces the formation of oxygen-deficient $\mathrm{BaCoO} 3-\lambda$ which promotes the trap of NOx on oxygen vacancies; however, when the synthesis temperature is lower than $700{ }^{\circ} \mathrm{C}$, surface areas may significantly contribute to the quantity of absorbed species [42]. For the sample LaA10.25Co0.75O3 calcined at different temperatures (Fig. $6 \mathrm{~b}$ ), the one annealed at $500{ }^{\circ} \mathrm{C}$ releases the most $\mathrm{NOx}$ with a value of $258 \mu \mathrm{mol} \mathrm{g}^{-1}$ in comparison with 45 and $61 \mu \mathrm{mol} \mathrm{g}{ }^{-1}$ of LaA10.25Co0.75O3 calcined at 600 and $700{ }^{\circ} \mathrm{C}$ respectively. On the other hand, the specific surface areas of the sample decrease from $\sim 22$ to $\sim 16 \mathrm{~m} 2 \mathrm{~g}^{-1}$ with calcination temperature from 500 to $600{ }^{\circ} \mathrm{C}$, and drops to $13.1 \mathrm{~m}^{2} \mathrm{~g}^{-1}$ at $700{ }^{\circ} \mathrm{C}$. Furthermore, it can be seen that calcination temperature from 700 to $600^{\circ} \mathrm{C}$ shifts the desorption peak of NOx by around $96{ }^{\circ} \mathrm{C}$, whereas sample calcined at $500{ }^{\circ} \mathrm{C}$ possesses the highest desorption temperature at $420^{\circ} \mathrm{C}$. The presence of $\mathrm{La} 2 \mathrm{O} 3$ in the samples calcined at low temperatures may be attributed to a stronger bond with NOx and higher adsorbed quantity since La2O3 is supposed as the main NOx storage site [43].

In many works for NOx storage and reduction, NO is fed with $\mathrm{O} 2$ to be oxidized to NO2 which is more readily trapped by basic catalysts [77]. In the present study, NO and NO2 are supplied in an approximately equal amount at $250{ }^{\circ} \mathrm{C}$ without the presence of $\mathrm{O} 2$. However, NO2 almost disappears while NO is higher than its original value $(250 \mathrm{ppm})$ during the adsorption process over LaCoO3 (Fig.6d). This behavior cannot be found in other samples (for example LaA10.25Co0.75O3 in Fig. 6d) where both NO and NO2 gets saturated after around 10 min. This suggests that during the NOx adsorption at $250{ }^{\circ} \mathrm{C}, \mathrm{NO} 2$ may be adsorbed and partially reduced to NO. This is confirmed by the presence of more intense peaks of $\mathrm{Co} 3 \mathrm{O} 4$ and $\mathrm{La} 2 \mathrm{O} 3$ phases in XRD pattern of $\mathrm{LaCoO} 3$ after TPD treatment, which may be a result of $\mathrm{Co}^{3+}$ to $\mathrm{Co}^{4+}$ oxidation by $\mathrm{NO} 2$ reduction. Moreover, the NOx-TPD of $\mathrm{LaCoO} 3$ shows no NO2 peaks whereas $\mathrm{NO}$ is 
desorbed at significantly higher than those of other samples (Fig. 6c). The difference between NO adsorption (calculated by integration of NO adsorption curve with time) and desorption is 88.2 $\mu \mathrm{mol} \mathrm{g}^{-1}$, indicating the additional amount of NO from NO2 reduction. It should be mentioned that $\mathrm{NO} 2$ can be adsorbed by basic La2O3 observed in XRD pattern for $\mathrm{LaCoO} 3$ to form nitrate salt, which can be decomposed at higher temperature than that in the experiment [79]. It may be suggested that $\mathrm{NO} 2$ may be adsorbed on $\mathrm{LaCoO} 3$ and completely reduced to other species together with both $\mathrm{Co}^{4+}$ formation and partially perovskite structure collapse.

\subsection{Catalytic activities}

\subsubsection{NO oxidation}

The NO oxidation tests aim at investigating the NO2 production at low temperatures, which is beneficial for the NOx storage/reduction process and soot combustion [77]. Fig. 7a shows NO to NO2 conversion profiles obtained from the isothermal mode, whereas the dashed line represents the thermodynamic equilibrium of NO oxidation reaction as a reference. The peaks of the curves indicate the temperatures where maximum NO2 generation is achieved. At temperatures below the peak temperature the NO oxidation is kinetically limited, while at higher temperatures the thermodynamic equilibrium is the limiting factor. Among the as-prepared samples, LaA10.25Co0.75O3 perovskite presents the best performance (Table 7), with a maximum NO conversion of about $78 \%$ at $320^{\circ} \mathrm{C}$.
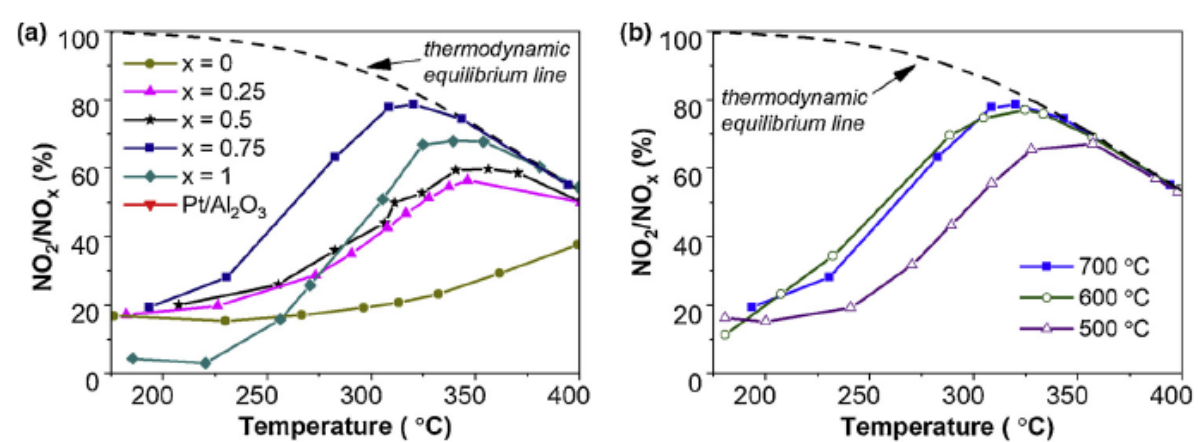

Fig. 7.
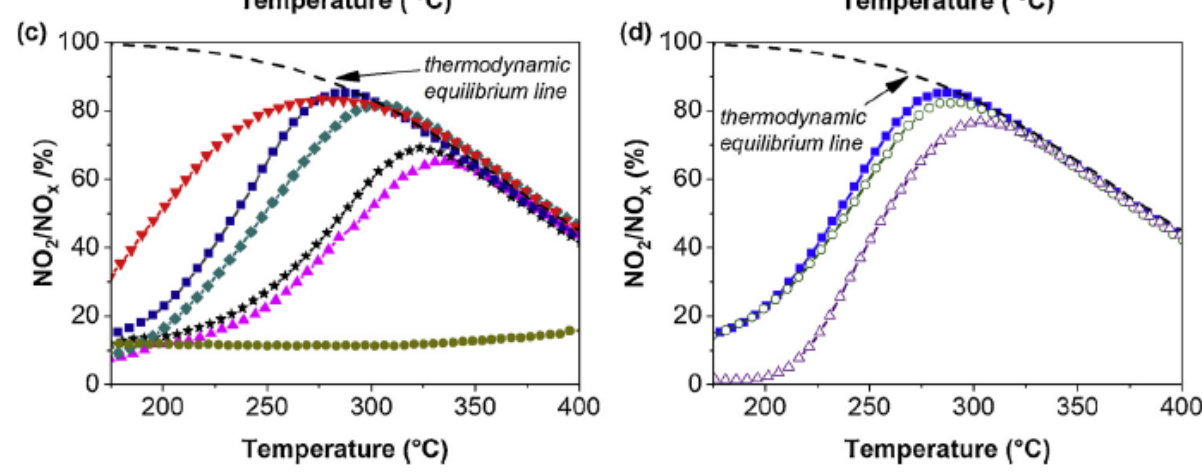

NO2 percentage of (a)

LaAl1-xCoxO3

calcined at $700^{\circ} \mathrm{C}$ and

(b) LaAl0.25Co0.75O3

calcined at different

temperatures in steady

state conditions and

(c) LaAl1-xCoxO3

calcined at $700{ }^{\circ} \mathrm{C}$ and

(d) LaAl0.25Co0.75O3

calcined at different

temperatures in

dynamic conditions.

\begin{tabular}{llll}
\hline Catalysts & $\mathrm{LaAl}_{1-\mathrm{x}} \mathrm{Co}_{\mathrm{x}} \mathrm{O}_{3}(\mathrm{x})$ & $\mathrm{NO}_{2} / \mathrm{NO}_{\mathbf{x}}(\%)$ & $\begin{array}{l}\text { Temperature } \\
\left({ }^{\circ} \mathrm{C}\right)\end{array}$ \\
\hline $\mathrm{LaAlO}_{3}$ & 0 & 38 & 399 \\
$\mathrm{LaAl}_{0.75} \mathrm{Co}_{0.25} \mathrm{O}_{3}$ & 0.25 & 56 & 346 \\
$\mathrm{LaAl}_{0.5} \mathrm{Co}_{0.5} \mathrm{O}_{3}$ & 0.5 & 60 & 356 \\
$\mathrm{LaAl}_{0.25} \mathrm{Co}_{0.75} \mathrm{O}_{3}$ & 0.75 & 78 & 320 \\
$\mathrm{LaCoO}_{3}$ & 1 & 68 & 339 \\
\hline
\end{tabular}

Table 7. NOx performances of LaCo1-xAlxO3 calcined at $700{ }^{\circ} \mathrm{C}$. 
In contrast, LaAlO3 exhibits the worst activity with $38 \%$ at a remarkably high temperature of about $399{ }^{\circ} \mathrm{C}$ and the $\mathrm{NO}$ conversion increases with $\mathrm{Co}$, from $38 \%$ for $\mathrm{LaAlO} 3$ to 56 and $60 \%$ for $\mathrm{LaA} 10.75 \mathrm{Co} 0.25 \mathrm{O} 3$ and $\mathrm{LaA} 10.5 \mathrm{Co} 0.5 \mathrm{O} 3$ catalysts, respectively. The conversion reaches the maximum value for $\mathrm{LaA} 10.25 \mathrm{Co} 0.75 \mathrm{O} 3$ before reverting to $68 \%$ when $\mathrm{Al}$ is totally substituted by $\mathrm{Co}$ as reported for $\mathrm{LaCoO} 3$ [20]. The same catalysts were also tested in the temperature ramping mode and under lower residence time (Fig. 7c and d) in order to obtain the same test conditions as the soot oxidation tests and to get a closer correlation between the two kind of experiments. As can be appreciated, the order of the catalytic performance (LaA10.25Co0.75O3 $>\mathrm{LaCoO} 3>$ $\mathrm{LaA} 10.5 \mathrm{Co} 0.5 \mathrm{O} 3>\mathrm{LaA} 10.75 \mathrm{Co} 0.25 \mathrm{O} 3>\mathrm{LaAlO} 3)$ was the same in both steady state and dynamic conditions.

Furthermore, by comparing the LaA10.25Co0.75O3 sample with a Pt/A12O3 commercial oxidation catalyst, the NO oxidation rate of the perovskite is obviously lower although the equilibrium is reached by both catalysts at almost the same temperature, which is the one of interest for the soot oxidation, offering a viable alternative for the PGM-based catalysts under certain conditions. It should be noticed that NO-to-NO2 oxidation ability is due to the generation of oxygen defects and redox property [80], which can be created by adjusting cation doping at A or B sites in the perovskite compounds. Others suggest that higher oxidation capacity is associated with higher oxygen mobility and exchange between lattice oxygen and gas phase oxygen [20]. This may be related to LaA10.25Co0.75O3 with the higher amount of $\beta$-oxygen desorption (Table 4), implying the pivotal role of lattice oxygen species in the improvement of the oxidation reaction.

Furthermore, all samples have negligible $\alpha$-oxygen quantity released during O2-TPD experiment, but still possess comparable NO oxidation activity. This result indicates that surface oxygen may not play a critical role in NO oxidation but the diffusion of lattice oxygen to the surface is more important [81]. However, $\mathrm{LaCoO} 3$ desorbs significantly more oxygen than its rivals (LaA10.75Co0.25O3 and LaA10.5Co0.5O3) but its oxidation activity worsens despite more Co content. The higher NOx desorption temperature for $\mathrm{LaCoO} 3$ indicates strong interactions between NOx and the catalyst, while partial doping Al slightly weakens the bonds facilitating the NOx release at low temperatures. Thus, oxygen mobility may be not the only factor for NO oxidation but the synergetic interaction between two B-site cations ( $\mathrm{Al}$ and $\mathrm{Co}$ ) may enhance oxidation performance of the catalysts, as suggested by $\mathrm{Ma}$ et al. with a small substitution of Co by Fe to promote NO conversion [82]. Furthermore, under H2/Ar flow in the H2-TPR experiment, LaA10.25Co0.75O3 is reduced at a temperature of $437{ }^{\circ} \mathrm{C}$, higher than $394{ }^{\circ} \mathrm{C}$ for LaA10.75Co0.25O3. However, the NO conversions of these samples reveal different trend for the reduction temperature, which may imply the negligible effects of reducibility on NO oxidation. Furthermore, LaCoO3 produces less $\mathrm{NO} 2$ at low temperatures but higher above $275{ }^{\circ} \mathrm{C}$ than LaA10.75Co0.25O3 and LaA10.5Co0.5O3 (Fig. 7a). This may be related to the fact that $\mathrm{LaCoO} 3$ can adsorb NO2 at low temperatures and partially reduce to NO, as can be seen in the NOx-TPD experiment. Besides, the temperature of maximum $\mathrm{NO} 2$ production is lowest for LaAl0.25Co0.75O3 at $320{ }^{\circ} \mathrm{C}$, and increases by around $30{ }^{\circ} \mathrm{C}$ with $\mathrm{x}=0.25$ and 0.5 (Table 7). A similar trend can be found for NO desorption profiles (Table 6), where NO desorbs at $320^{\circ} \mathrm{C}$ for $\mathrm{LaA} 10.25 \mathrm{Co} 0.75 \mathrm{O} 3$ and increase to 350 and $347^{\circ} \mathrm{C}$ for $\mathrm{LaA} 10.5 \mathrm{Co} 0.5 \mathrm{O} 3$ and $\mathrm{LaA} 10.75 \mathrm{Co} 0.25 \mathrm{O} 3$ respectively. This highlights the suggestion in which the oxidation reaction commences with the chemisorption of reactants $\mathrm{NO}$ and $\mathrm{O} 2$, followed by the dissociation of $\mathrm{O} 2$ and NO2 on the surface [28].

Many works have found that substitutions of A-site generate oxygen vacancies, for example La1xSrxBO3 [20,43], or of B-site to support the co-existence of multivalent states, e.g. LaCo1- 
xMgxO3 [67], in order to promote NO oxidation. Furthermore, it was shown that the partial substitution of cations can promote the formation of preferential oxidation active states (e.g. metallic isolated or biactive sites) that can promote the NO oxidation [83,84]. However, there are fewer investigations regarding the effect of the degree of perovskite crystallinity on the NO oxidation. Fig. $7 \mathrm{~b}$ shows profiles of $\mathrm{NO} 2$ molar percentage in the NOx mixture of LaA10.25Co0.75O3 which is calcined at 500, 600 and $700{ }^{\circ} \mathrm{C}$. It is clear that the sample annealed at $500{ }^{\circ} \mathrm{C}$ reveals the lowest oxidation activity, with about $66 \%$ at $\sim 350{ }^{\circ} \mathrm{C}$ despite the highest surface area $(21.9 \mathrm{~m} 2 \mathrm{~g}-1)$, probably due to the presence of segregated phases such as $\mathrm{Co} 3 \mathrm{O} 4$ and La2O3 [20]. The samples calcined at $600{ }^{\circ} \mathrm{C}$ show superior oxidation performances at low temperatures, but at above $300{ }^{\circ} \mathrm{C}$ the solid calcined at $700{ }^{\circ} \mathrm{C}$ slightly outperforms. Despite the reduction in surface area, the calcination temperature up to $700{ }^{\circ} \mathrm{C}$ has positive effects on oxidation activity, which may be associated with higher crystallinity and less minor phases as detected in XRD profiles (Fig. 2b). However, further increase calcination temperature beyond $700{ }^{\circ} \mathrm{C}$ may lead to deterioration of oxidation activity due to low surface area as studied elsewhere [20].

\subsubsection{Soot oxidation}

Fig. 8 reveals the results of soot oxidation tests over LaAl0.25Co0.75O3 (calcined at $700{ }^{\circ} \mathrm{C}$ ) in the presence and absence of NOx gas. Table 8 shows the testing outputs: T10\% represents the ignition temperature, when $10 \%$ of soot is burnt; T50\% and T90\% are the temperatures when $50 \%$ and $90 \%$ of soot is consumed respectively; Tmax is the temperature when maximum $\mathrm{CO} 2$ production is achieved, and (NO2/NOx)max/T is the maximum percentage of NO2 over NOx mixture and its temperature. Generally, the NOx-assisted soot oxidation reaction starts with the oxidation of adsorbed NO to produce NO2, which is a stronger oxidant than $\mathrm{O} 2[38,45,85]$. Soot can be also oxidized by $\mathrm{O} 2$ but at a relatively higher temperature than with $\mathrm{NO} 2$. In the presence of NO2, it interacts with soot surface to form surface oxygen complexes (SOC), which decomposes further to $\mathrm{CO}, \mathrm{CO} 2$ and $\mathrm{NO}[28,86]$. O2 is first adsorbed at the catalyst's surface and undergoes the dissociation to form active oxygen species. This species is possibly transferred to the surface of soot forming SOC via spill-over mechanism [86]. The results clearly show that soot is oxidized at a significantly lower temperature in the presence of $\mathrm{NOx}\left(\mathrm{T} 10 \%\right.$ are 377 and $513{ }^{\circ} \mathrm{C}$ for with and without NOx respectively).
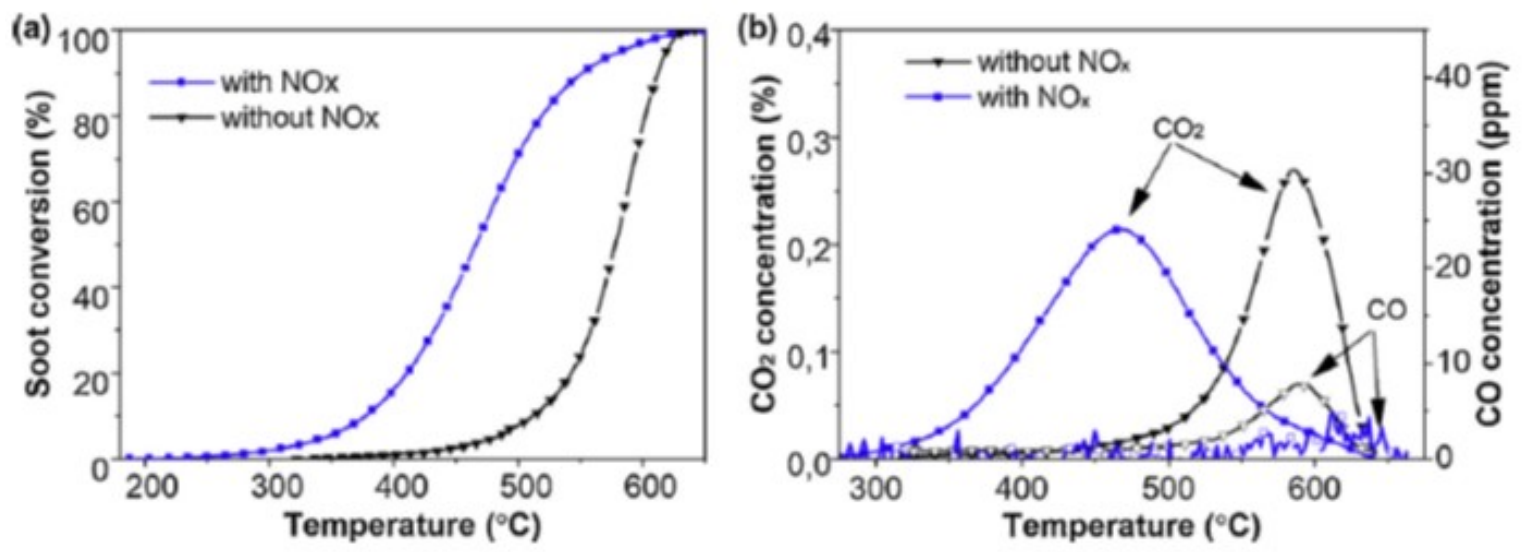

Fig. 8. (a) Soot conversion and (b) $\mathrm{CO} 2$ and $\mathrm{CO}$ concentration as function of temperature during soot oxidation catalytic tests with and without NOx supply over LaAl0.25Co0.75O3 catalyst. 
Table 8. Catalytic performances of LaCo1-xAlxO3 calcined at $700{ }^{\circ} \mathrm{C}$.

\begin{tabular}{|c|c|c|c|c|c|c|c|}
\hline $\mathrm{LaAl}_{1-x} \mathrm{Co}_{\mathrm{x}} \mathrm{O}_{3}$ & $\mathrm{x}$ & $\begin{array}{l}\mathrm{T}_{10 \%} \\
\left({ }^{\circ} \mathrm{C}\right)\end{array}$ & $\begin{array}{l}\mathrm{T}_{50 \%} \\
\left({ }^{\circ} \mathrm{C}\right)\end{array}$ & $\mathrm{T}_{\max }\left({ }^{\circ} \mathrm{C}\right)$ & $\mathrm{T}_{90 \%}\left({ }^{\circ} \mathrm{C}\right)$ & $\left(\mathrm{NO}_{2} / \mathrm{NO}_{\mathrm{x}}\right)_{\max } / \mathrm{T}\left({ }^{\circ} \mathrm{C}\right)$ & $\mathrm{CO}_{2}$ selectivity (\%) \\
\hline $\mathrm{LaAlO}_{3}$ & 0 & 470 & 562 & 563 & 623 & $0.08 / 376$ & 82.3 \\
\hline $\mathrm{LaAl}_{0.75} \mathrm{Co}_{0.25} \mathrm{O}_{3}$ & 0.25 & 402 & 484 & 481 & 560 & $0.39 / 383$ & 98.7 \\
\hline $\mathrm{LaAl}_{0.5} \mathrm{Co}_{0.5} \mathrm{O}_{3}$ & 0.5 & 401 & 487 & 482 & 570 & $0.44 / 379$ & 98.1 \\
\hline $\mathrm{LaAl}_{0.25} \mathrm{Co}_{0.75} \mathrm{O}_{3}$ & 0.75 & 377 & 467 & 467 & 585 & $0.71 / 321$ & 99.8 \\
\hline $\mathrm{LaCoO}_{3}$ & 1 & 389 & 467 & 493 & 624 & $0.40 / 352$ & 93.8 \\
\hline Without $\mathrm{NO}_{\mathrm{x}}$ & - & 513 & 578 & 587 & 612 & $-1-$ & 98.5 \\
\hline $\mathrm{SiC}$ & - & 532 & 610 & 626 & 640 & $-1-$ & 50.7 \\
\hline
\end{tabular}

Moreover, NOx also remarkably supports to reduce the temperature of $50 \%$ of soot conversion by around $111^{\circ} \mathrm{C}$ although at higher temperatures the role of NOx in soot oxidation becomes less prominent with the decrease of T90\% by only $27^{\circ} \mathrm{C}$ because of limited NOx availability (Table 8). In terms of $\mathrm{CO} 2$ production, NOx promotes the total oxidation with $\mathrm{CO} 2$ selectivity of $99.8 \%$ compared to $98.5 \%$ of that without NOx. Without the presence of NOx, the Tmax increases by around $120^{\circ} \mathrm{C}$ and the formation of $\mathrm{CO}$ is significant. The results highlight the vital role of NO2 in soot oxidation and its further applications in NOx reduction process by the selective catalytic reduction reaction.

Fig. 9 summarizes soot conversion, $\mathrm{NO} 2 / \mathrm{NOx}$ percentage, $\mathrm{CO}$ and $\mathrm{CO} 2$ concentrations as functions of temperature during the experiments with NOx-assisted soot oxidation over LaAl1$\mathrm{xCoxO} 3$ catalysts. Among the prepared solids, $\mathrm{LaAlO} 3$ possesses certainly the lowest activity with $\mathrm{T} 10 \%, \mathrm{~T} 50 \%$ and $\mathrm{T} 90 \%$ of 470,562 and $623{ }^{\circ} \mathrm{C}$ respectively. Doping Co shifts the reaction temperature to lower ranges, $\mathrm{LaA} 10.75 \mathrm{Co} 0.25 \mathrm{O} 3$ obviously outperforms $\mathrm{LaAlO} 3$ by reducing these temperature values by about $60-80{ }^{\circ} \mathrm{C}$.
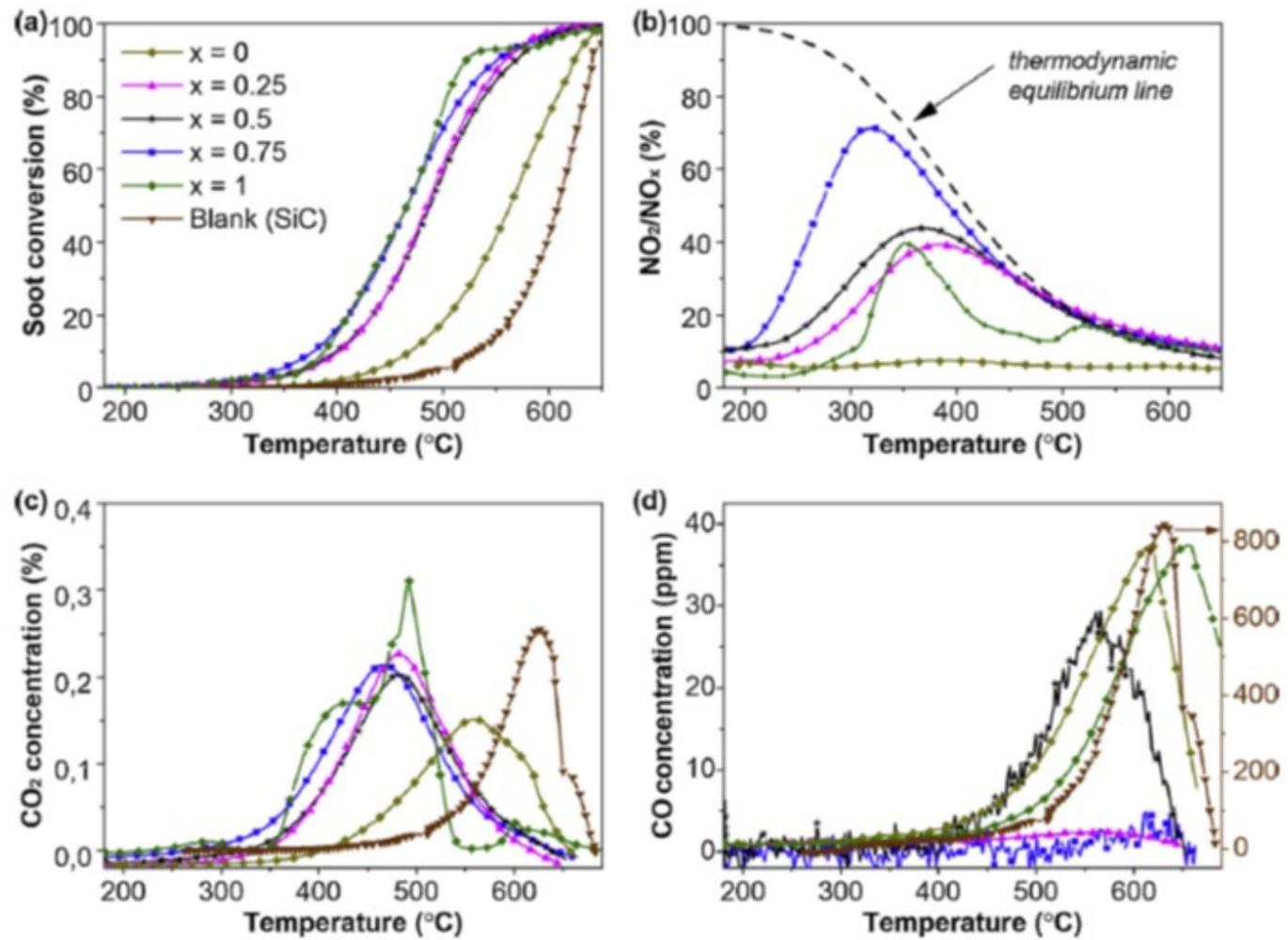

Fig. 9. (a) Soot conversion, (b) NO2 percentage, (c) CO2 and (d) CO concentrations of LaAll-xCoxO3 calcined at $700{ }^{\circ} \mathrm{C}$. 
The improvement in the oxidation activity is likely to be related to not only the better performance in the NOx oxidation but also the NOx adsorption [35], as the Co doping reduces the NOx desorption temperature thereby facilitating the oxidation reactions at a lower temperature range (Fig. 6). As expected, both samples $\mathrm{LaA} 10.75 \mathrm{Co} 0.25 \mathrm{O} 3$ and $\mathrm{LaA} 10.5 \mathrm{Co} 0.5 \mathrm{O} 3$ (violet and black curves) exhibit similar soot oxidation activity, which is in line with the NOx-TPD experiments. This suggests that the NOx-assisted soot oxidation is mainly governed by the adsorption of NOx on the catalyst's surface and directed to the soot-catalyst interface before initiation of the oxidation [35]. LaAl0.25Co0.75O3 is the most active catalyst with $\mathrm{T} 10 \%$ of $377^{\circ} \mathrm{C}$, which is $12{ }^{\circ} \mathrm{C}$ lower than that of $\mathrm{LaCoO} 3$. The complete substitution of $\mathrm{Al}$ by Co deteriorates the soot oxidation performance at low temperatures while there is no difference at middle temperature with $\mathrm{T} 50 \%$ of $467{ }^{\circ} \mathrm{C}$ for both $\mathrm{LaAl} 10.25 \mathrm{Co} 0.75 \mathrm{O} 3$ and $\mathrm{LaCoO}$. The difference between these two catalysts is signified in terms of $\mathrm{NO} 2$ production which plays an essential role in abatement reduction. LaA10.25Co0.75O3 maintains high formation of $\mathrm{NO} 2$ with $\mathrm{NO} 2 / \mathrm{NOx}$ of 0.71 at $321^{\circ} \mathrm{C}$ compared to 0.42 at $352{ }^{\circ} \mathrm{C}$ for $\mathrm{LaCoO} 3$. The low ignition temperature allows to uninterruptedly oxidize soot while keeping high NO2 production. In comparison with soot-free NO oxidation, NO2 production obtained from NOx-soot oxidation for all catalysts is lower, confirming the participation of NO2 as a strong oxidant in the reaction leading to its consumption.

LaAlO3 shows no formation of $\mathrm{NO} 2$ at all, explaining that the soot oxidation is practically the same as non-catalytic [86]. The outstanding performance of LaAl0.25Co0.75O3 is likely to be associated with the prominent lattice oxygen mobility which may be facilitated by coincorporation of Co-Al elements in perovskite structure [86,87]. Fig. 9c and d show the evolution of $\mathrm{CO} 2$ and $\mathrm{CO}$ concentration during the NOx-assisted oxidation tests over the catalysts with various Co content. Obviously, $\mathrm{LaAlO} 3$ has the highest Tmax (the temperature at which the maximum $\mathrm{CO} 2$ is produced) at $563{ }^{\circ} \mathrm{C}$ with low quantity of $\mathrm{CO} 2$ formed, evidenced by the $\mathrm{CO} 2$ selectivity of $82.3 \%$. The substitution of Co by Al shifts the Tmax to lower range by about $81^{\circ} \mathrm{C}$ for $\mathrm{x}=0.25$ and 0.5 , and by around $96{ }^{\circ} \mathrm{C}$ for $\mathrm{LaA} 10.25 \mathrm{Co} 0.75 \mathrm{O} 3$. However, $\mathrm{LaCoO} 3$ shifts the temperature towards $493{ }^{\circ} \mathrm{C}$ which is similar to that reported elsewhere [27] and produces relatively a large amount of $\mathrm{CO}$ at high temperature. The $\mathrm{CO} 2$ evolution profile for $\mathrm{LaCoO} 3$ has a relatively similar trend as NO desorption curve with a broader shoulder at a low-temperature range (Fig. 6c), indicating the key role of $\mathrm{NO}$ adsorption on soot oxidation. When $\mathrm{SiC}$ was used as a reference for the non-catalytic soot oxidation, the promotional effect of NOx was lost as the peak of the soot oxidation rate was shifted to $626^{\circ} \mathrm{C}$ coupled with a very high CO production.

Fig. 10 summarizes soot conversion and $\mathrm{NO} 2 / \mathrm{NOx}$ percentage as functions of temperature over catalyst LaA10.25Co0.75O3 calcined at different temperatures, and Table 9 sums up the oxidative characteristics of the catalyst. The calcination at lower temperatures enhances the surface areas but deteriorates the oxidation activity. The sample annealed at $500{ }^{\circ} \mathrm{C}$ has the highest $\mathrm{T} 10 \%, \mathrm{~T} 50 \%$ and $\mathrm{T} 90 \%$ at 399,492 and $583{ }^{\circ} \mathrm{C}$ respectively, compared to 370,478 and $578{ }^{\circ} \mathrm{C}$ for LaAl0.25Co0.75O3 calcined at $600{ }^{\circ} \mathrm{C}$. Moreover, the treatment at 600 and $700{ }^{\circ} \mathrm{C}$ shows similar soot oxidation but the $\mathrm{NO} 2$ production of the later is ameliorated with $71 \%$ compared to $64.9 \%$ for the former. It has been already mentioned that LaA10.25 Co $0.75 \mathrm{O} 3$ calcined at the lowest temperature adsorbs the largest amount of NO due to high surface area but releases this gas at the highest temperature, suggesting that stronger interaction between NOx and substrate surface does not support the oxidation reaction and the products fail to dissociate as it can be described by the Sabatier principle [88]. This finding emphasizes the crucial role of crystallinity promoted by high calcination temperature in both $\mathrm{NO}$ and NOx-assisted soot oxidation. 
(a)

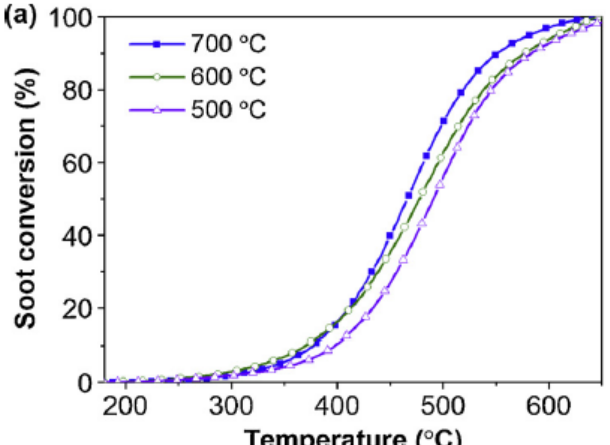

Calcination

Temperature

$\left({ }^{\circ} \mathrm{C}\right)$

$\left({ }^{\circ} \mathrm{C}\right)$ (b) 1

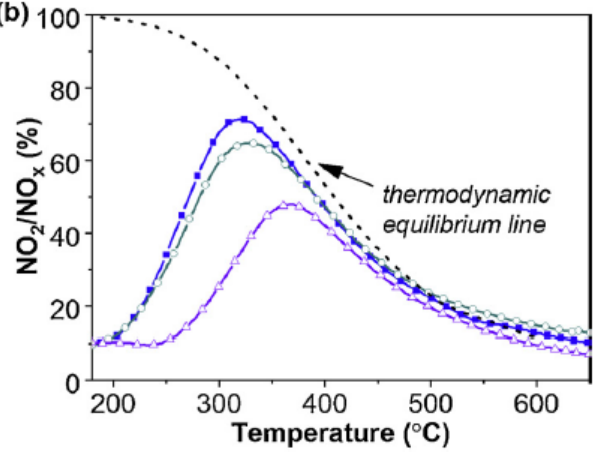

$\mathrm{T}_{10 \%} \quad \mathrm{~T}_{50 \%} \quad \mathrm{~T}_{\max }\left({ }^{\circ} \mathrm{C}\right)$

$\mathrm{T}_{90 \%}\left({ }^{\circ} \mathrm{C}\right)$

$\mathrm{CO}_{2}$

selectivity

$\left(\mathrm{NO}_{2} /\right.$
$\left.\mathrm{NO}_{x}\right)_{\max } /$
$\mathrm{T}$

(\%)

$\left(\% /{ }^{\circ} \mathrm{C}\right)$

\begin{tabular}{lllllll}
\hline 700 & 377 & 467 & 467 & 585 & $71.0 / 321$ & 99.8 \\
600 & 370 & 478 & 478 & 578 & $64.9 / 330$ & 99.5 \\
500 & 399 & 492 & 499 & 583 & $47.9 / 368$ & 98.7 \\
\hline
\end{tabular}

Fig. 10. (a) Soot oxidation and (b) NO2 percentage of aAl0.25Co0.75O3 calcined at different temperatures.

Table 9. Catalytic performances of LaAl0.25Co0.75O3 at different calcination temperatures.

\section{Conclusions}

Among the prepared catalysts, LaA10.25Co0.75O3 exhibits superior catalytic activity for both $\mathrm{NO}$ oxidation and NOx-assisted soot oxidation. For the NO oxidation, NO2 production can reach 78\% at relatively low temperature $\left(320^{\circ} \mathrm{C}\right)$ which is considered as a potential alternative for noble metal catalysts. Furthermore, LaA10.25Co0.75O3 is also the most active catalyst for NOx-assisted soot oxidation with $\mathrm{T} 10 \%$ of $377{ }^{\circ} \mathrm{C}$ and $\mathrm{NO} 2 / \mathrm{NOx}$ of 0.71 , and results in almost $100 \%$ of $\mathrm{CO} 2$ selectivity. The correlation between NOx desorption and oxidation activity is well established suggesting that NOx adsorption on catalyst surface is a key role in soot oxidation with NOx. The effect of NO2 for soot oxidation is obvious, since in its absence the oxidation activity remarkably decreases. The excellent performance of LaAl0.25Co0.75O3 is likely to be linked with high lattice surface oxygen supported by well-crystallized perovskite structure. Full replacement of Al by Co deteriorates the catalytic activity, suggesting that the combination of Al-Co has synergetic effects on the catalysis.

\section{Acknowledgements}

This work was co-funded through a SINCHEM Grant. SINCHEM (Sustainable Industrial Chemistry) is a Joint Doctorate programme selected under the Erasmus Mundus Action 1 Programme (FPA 2013-0037).

\section{References}

[1] M.A. Pena, J.L.G. Fierro, Chem. Rev. 101 (2001) 1981-2017.

[2] J. Zhu, H. Li, L. Zhong, P. Xiao, X. Xu, X. Yang, Z. Zhao, J. Li, ACS Catal. 4 (2014) 2917-2940.

[3] U. Oemar, P.S. Ang, K. Hidajat, S. Kawi, Int. J. Hydrogen Energy 38 (2013) 5525-5534.

[4] C.P.B. Quitete, R.L. Manfro, M.M.V.M. Souza, Int. J. Hydrogen Energy 42 (2017) 9873-9880. 
[5] Yasushi, D. Mukai, Y. Murai, S. Tochiya, Y. Izutsu, K. Sekiguchi, N. Hosomura, H. Arai, E. Kikuchi, Y. Sugiura, Appl. Catal. A Gen. 451 (2013) 160-167.

[6] K.H. Lin, C. Bin Wang, S.H. Chien, Int. J. Hydrogen Energy 38 (2013) 3226-3232.

[7] Q. Zhang, L. Li, B. Jiang, K. Wang, D. Tang, B. Dou, Int. J. Hydrogen Energy 42 (2017) 17102-17111.

[8] K. Zhao, F. He, Z. Huang, G. Wei, A. Zheng, H. Li, Z. Zhao, Appl. Energy 168 (2016) 193-203.

[9] L.D. Vella, J.A. Villoria, S. Specchia, N. Mota, J.L.G. Fierro, V. Specchia, Catal. Today 171 (2011) 84-96.

[10] T.H. Nguyen, A. Łamacz, P. Beaunier, S. Czajkowska, M. Domański, A. Krztoń, T. Van Le, G. DjégaMariadassou, Appl. Catal. B Environ 152-153 (2014) 360-369.

[11] S. Ramesh, N.J. Venkatesha, ACS Sustan. Chem. Eng. 5 (2017) 1339-1346.

[12] J. Yao, J. Liu, H. Hofbauer, G. Chen, B. Yan, R. Shan, W. Li, Energy Convers. Manage. 117 (2016) 343-350.

[13] G. Chen, J. Yao, J. Liu, B. Yan, R. Shan, W. Li, Bioresour. Technol. 198 (2015) 108-114.

[14] G. Chen, J. Yao, J. Liu, B. Yan, R. Shan, Renew. Energy 91 (2016) 315-322.

[15] K.A. Resende, C.N. Vila-Neto, R.C. Rabelo-Neto, F.B. Noronha, C.E. Hori, Catal. Today 242 (2015) 71-79.

[16] X. Yang, L. Yang, W. Fan, H. Lin, Catal. Today 269 (2016) 56-64.

[17] M.-Y. Chen, C.-B. Chen, B. Zada, Y. Fu, M.H. Qiao, K.N. Fan, X.X. Zhang, B.N. Zong, A. Sarkar, M.K. Nazeeruddin, M. Grätzel, S.I. Seok, Green Chem. 18 (2016) 3858-3866.

[18] H. Deng, L. Lin, Y. Sun, C. Pang, J. Zhuang, P. Ouyang, Z. Li, S. Liu, Catal. Lett. 126 (2008) 106-111.

[19] H. Deng, L. Lin, Y. Sun, C. Pang, J. Zhuang, P. Ouyang, J. Li, S. Liu, Energy Fuels 23 (2009) 19-24.

[20] J.A. Onrubia, J.R. González-velasco, Appl. Catal. B Environ. 213 (2017) 198-210.

[21] X. Yang, L. Luo, H. Zhong, Catal. Commun. 6 (2005) 13-17.

[22] A.K. Ladavos, P.J. Pomonis, Appl. Catal. A Gen. 165 (1997) 73-85.

[23] N. Russo, S. Furfori, D. Fino, G. Saracco, V. Specchia, Appl. Catal. B Environ. 83 (2008) 85-95.

[24] S. Irusta, M.P. Pina, M. Men, J. Catal. 412 (1998) 400-412.

[25] A. Russell, W.S. Epling, Catal. Rev. - Sci. Eng. 53 (2011) 337-423.

[26] A. Namdeo, M.C. Bell, Environ. Int. 31 (2005) 565-573.

[27] R. Zhang, N. Luo, B. Chen, S. Kaliaguine, Energy Fuels 24 (2010) 3719-3726.

[28] T. Andana, M. Piumetti, S. Bensaid, L. Veyre, C. Thieuleux, N. Russo, D. Fino, E. Alessandra, R. Pirone, Appl. Catal. B Environ. 209 (2017) 295-310.

[29] E. Xue, K. Seshan, J.R.H. Ross, Appl. Catal. B Environ. 11 (1996) 65-79.

[30] M.V. Twigg, Catal. Today 117 (2006) 407-418.

[31] A. Setiabudi, M. Makkee, J.A. Moulijn, Appl. Catal. B Environ. 50 (2004) 185-194.

[32] M. Koebel, M. Elsener, M. Kleemann, Catal. Today 59 (2000) 335-345.

[33] M. Koebel, G. Madia, M. Elsener, Catal. Today 73 (2002) 239-247.

[34] M.K. Majewski, W.A. Khair, Diesel Emiss. Their Control. SAE Int., Warrendale, PA, 2006.

[35] T. Andana, M. Piumetti, S. Bensaid, L. Veyre, C. Thieuleux, N. Russo, D. Fino, E.A. Quadrelli, R. Pirone, Appl. Catal. B Environ. 226 (2018) 147-161.

[36] S. Liu, X. Wu, H. Luo, D. Weng, R. Ran, J. Phys. Chem. C 119 (2015) 17218-17227.

[37] H. Zhang, Y. Zhu, S. Wang, M. Zhao, M. Gong, Y. Chen, Fuel Process. Technol. J. 137 (2015) 38-47.

[38] S. Liu, X. Wu, D. Weng, M. Li, R. Ran, ACS Catal. 5 (2015) 909-919.

[39] C.H. Kim, G. Qi, K. Dahlberg, W. Li, Science (80-) 327 (2010) 1624-1627.

[40] J. Wang, Y. Su, X. Wang, J. Chen, Z. Zhao, M. Shen, Catal. Commun. 25 (2012) 106-106.

[41] V. Torregrosa-Rivero, V. Albaladejo-Fuentes, M.S. Sanchez-Adsuar, M.J. Illan-Gomez, RSC Adv. Open 7 (2017) 35228-35238. 
[42] V.G. Milt, M.A. Ulla, E.E. Miro, Appl. Catal. B Environ. 57 (57) (2005) 13-21.

[43] N.T, P.V. Xin-Gang Li, Yan-Hua Dong, Hui Xian, Willinton Yesid Hernandez, Ming Meng, Hong-Hu Zou, AiJing Ma, Tian-Yong Zhang, Zheng Jiang, Energy Environ. Sci. 4 (2011) 3351-3354.

[44] J. Chen, M. Shen, X. Wang, J. Wang, Y. Su, Z. Zhao, Catal. Commun. 37 (2013) 105-108.

[45] F. Lin, X. Wu, S. Liu, D. Weng, Y. Huang, Chem. Eng. J. 226 (2013) 105-112.

[46] T.R. Sahoo, M. Armandi, R. Arletti, M. Piumetti, S. Bensaid, M. Manzoli, S.R. Panda, B. Bonelli, Appl. Catal. B Environ. 211 (2017) 31-45.

[47] H. Lehnert, H. Boysen, J. Schneider, F. Frey, D. Hohlwein, P. Radaelli, H. Ehrenberg, Z. Kristallogr. Cryst. Mater. 215 (2000) 536.

[48] C.J. Howard, B.J. Kennedy, B.C. Chakoumakos, J. Phys. Condens. Matter 12 (2000) 349-365.

[49] G. Thornton, B.C. Tofield, A.W. Hewat, J. Solid State Chem. 61 (1986) 301-307.

[50] V. Aswin, P. Kumar, P. Singh, A. Gupta, S. Rayaprol, A. Dogra, J. Mater. Sci. 50 (2015) 366-373.

[51] R.D. Shannon, Acta Cryst (1976) 751.

[52] X. Zhu, X. Tu, M. Chen, Y. Yang, C. Zheng, J. Zhou, X. Gao, Catal. Commun. 92 (2017) 35-39.

[53] N.A. Merino, B.P. Barbero, P. Ruiz, L.E. Cadús, J. Catal. 240 (2006) 245-257.

[54] J. Zhang, X. Weng, Z. Wu, Y. Liu, H. Wang, Appl. Catal. B Environ. 126 (2012) 231-238.

[55] S. Ivanova, A. Senyshyn, E. Zhecheva, K. Tenchev, V. Nikolov, R. Stoyanova, H. Fuess, J. Alloys Compd. 480 (2009) 279-285.

[56] N.A. Merino, B.P. Barbero, P. Grange, L.E. Cadús, J. Catal. 231 (2005) 232-244.

[57] B. Białobok, J. Trawczyński, W. Miśta, M. Zawadzki, Appl. Catal. B Environ. 72 (2007) 395-403.

[58] T. Nakamura, G. Petzow, L.J. Gauckler, Mater. Res. Bull. 14 (1979) 649-659.

[59] B. Levasseur, S. Kaliaguine, Appl. Catal. A Gen. 343 (2008) 29-38.

[60] L.B. Sis, G.P. Wirtz, S.C. Sorenson, J. Appl. Phys. 44 (1973) 5553.

[61] L. Huang, M. Bassir, S. Kaliaguine, Appl. Surf. Sci. 243 (2005) 360-375.

[62] O.O. James, S. Maity, J. Pet, Technol. Altern. Fuels 7 (2016) 1-12.

[63] R. Sarbajna, A.S. Devi, K. Purandhar, M.V. Suryanarayana, Int. J. Chemtech Res. 5 (2013) 2810-2820.

[64] R. Zhang, A. Villanueva, H. Alamdari, S. Kaliaguine, Appl. Catal. B Environ. 64 (2006) 220-233.

[65] R. Pereñíguez, J.L. Hueso, F. Gaillard, J.P. Holgado, A. Caballero, Catal. Lett. 142 (2012) 408-416.

[66] S. Royer, F. Bérubé, S. Kaliaguine, Appl. Catal. A Gen. 282 (2005) 273-284.

[67] J. Zhang, D. Tan, Q. Meng, X. Weng, Z. Wu, Appl. Catal. B, Environ. 172-173 (2015) 18-26.

[68] R.R. Solís, F.J. Rivas, O. Gimeno, Appl. Catal. B Environ. 200 (2017) 83-92.

[69] M. O'Connell, A. Norman, C. Hüttermann, M. Morris, Catal. Today 47 (1999) 123-132.

[70] C.A.F. Vaz, D. Prabhakaran, E.I. Altman, V.E. Henrich, Phys. Rev. B - Condens. Matter Mater. Phys. 80 (2009) $1-7$.

[71] C.A. Chagas, F.S. Toniolo, R.N.S.H. Magalhães, M. Schmal, Int. J. Hydrogen Energy 37 (2012) 5022-5031.

[72] M.C. Biesinger, B.P. Payne, A.P. Grosvenor, L.W.M. Lau, A.R. Gerson, R.S.C. Smart, Appl. Surf. Sci. 257 (2011) 2717-2730.

[73] F. Fang, N. Feng, L. Wang, J. Meng, G. Liu, P. Zhao, P. Gao, J. Ding, Appl. Catal. B Environ. 236 (2018) 184 194.

[74] C. Lee, Y. Jeon, S. Hata, J. Park, R. Akiyoshi, H. Saito, Y. Teraoka, Y. Shul, H. Einaga, Appl. Catal. B Environ. 191 (2016) 157-164.

[75] X. He, M. Meng, J. He, Z. Zou, X. Li, Z. Li, Z. Jiang, Catal. Commun. 12 (2010) 165-168.

[76] R. You, Y. Zhang, D. Liu, M. Meng, Z. Jiang, S. Zhang, Y. Huang, Chem. Eng. J. 260 (2015) 357-367.

[77] S. Roy, A. Baiker, Chem. Rev. 109 (2009) 4054-4091. 
[78] J. Liu, Z. Zhao, C. Xu, A. Duan, G. Jiang, J. Phys. Chem. C 112 (2008) 5930-5941.

[79] S. Mentus, D. Jelić, V. Grudić, J. Therm. Anal. Calorim. 90 (2007) 393-397.

[80] Y. Peng, W. Si, J. Luo, W. Su, H. Chang, J. Li, J. Hao, J. Crittenden, Environ. Sci. Technol. 50 (2016) 64426448.

[81] J. Chen, M. Shen, X. Wang, G. Qi, J. Wang, W. Li, Appl. Catal. B Environ. 134-135 (2013) 251-257.

[82] A.-J. Ma, S.Z. Wang, C. Liu, H. Xian, Q. Ding, L. Guo, M. Meng, Y.S. Tan, N. Tsubaki, J. Zhang, L.R. Zheng, X.G. Li, Appl. Catal. B Environ. 146 (2014) 24-34.

[83] J. Xiong, Q. Wu, X. Mei, J. Liu, Y. Wei, Z. Zhao, D. Wu, J. Li, ACS Catal. 8 (2018) 7915-7930.

[84] P. Ciambelli, S. Cimino, G. Lasorella, L. Lisi, S. De Rossi, M. Faticanti, G. Minelli, P. Porta, Appl. Catal. B Environ. 37 (2002) 231-241.

[85] K. Tikhomirov, O. Kröcher, M. Elsener, A. Wokaun, Appl. Catal. B Environ. 64 (2006) $72-78$.

[86] N.D. Wasalathanthri, T.M. SantaMaria, D.A. Kriz, S.L. Dissanayake, C.H. Kuo, S. Biswas, S.L. Suib, Appl. Catal. B Environ. 201 (2017) 543-551.

[87] C.M. Marcos, V.T. Rivero, V.A. Fuentes, M.S.S. Adsuar, M.J.I. Gómez, Top. Catal. 0 (2018) 0.

[88] G. Rothenberg, Catalysis: Concepts and Green Applications, WILEY-VCH Verlag, 2008. 